\title{
28. ORGANIC PETROGRAPHY AND EXTRACTABLE HYDROCARBONS OF SEDIMENT FROM THE GULF OF CALIFORNIA, DEEP SEA DRILLING PROJECT LEG $64^{1}$
}

\author{
Jürgen Rullkötter, Institut für Erdöl und Organische Geochemie, \\ Kernforschungsanlage Jülich GmbH, D-5170 Jülich, Federal Republic of Germany, \\ Hans von der Dick, Lehrstuhl für Geologie, Geochemie und Lagerstätten des Erdöls und der Kohle, \\ Rheinisch-Westfälische Technische Hochschule, D-5100 Aachen, Federal Republic of Germany, \\ and \\ Dietrich H. Welte, Institut für Erdöl und Organische Geochemie, \\ Kernforschungsanlage Jülich GmbH, D-5170 Jülich, Federal Republic of Germany
}

\begin{abstract}
We determined the quantity, type, and maturity of organic matter in Pleistocene sediment from the Gulf of California. We analyzed extractable hydrocarbons by capillary column chromatography and combined gas chromatography/mass spectrometry (GC/MS). We investigated kerogens by Rock-Eval pyrolysis and microscopy. Organic carbon is mostly between 1 and $2 \%$ in samples from the mouth of the Gulf (Holes 474 and 474A) and in the Guaymas Basin (Holes 478, 481, and 481A) and between 2 and $4 \%$ at the Guaymas Basin slope (Hole 479). We determined total extracts of about $10 \mathrm{mg} / \mathrm{g} \mathrm{C}_{\text {org }}$ for all samples. The organic matter seems to be mostly terrigenous in Holes 474, 474A, 478, 481, and $481 \mathrm{~A}$, as indicated by the extractable hydrocarbons and the maceral analysis. But we believe that the large amounts of steroid and triterpenoid hydrocarbons in some samples indicate marine and bacterial biomass, which probably is finely disseminated and cannot readily be identified under the microscope. Rederived, inert organic matter is common in these holes. In Hole 479, the terrigenous contribution is less pronounced, and algal liptinites exceed terrigenous liptinites. But in all samples, perylene is the predominant aromatic hydrocarbon. Optical and chemical investigations show that the organic matter in the Gulf of California sediment is immature, despite the high heat flow and local basaltic intrusions. We could not establish a regular maturity trend with increasing depth.
\end{abstract}

\section{INTRODUCTION}

Sediment was recovered in three areas of the Gulf of California during Deep Sea Drilling Project (DSDP) Leg 64. Site 474 (water depth $=3023 \mathrm{~m}$ ) is outside the foot of the continental slope and near the mouth of the Gulf. Pliocene through Pleistocene sediment consists mainly of diatomaceous mud and mud turbidites. Three dolerite sills occur near the base of Hole 474A. Sites 478 and 481 (water depths $=1889$ and $1998 \mathrm{~m}$, respectively) are in the Guaymas Basin in the axis of the central Gulf. Upper Quaternary turbidites are predominant in the holes of both sites, but laminated diatomaceous mudstones also occur frequently. Dolerite sills were observed within the sediment. Some of the older sediment may have been deposited in a reducing environment, the result of a silled, deep basin with stagnant watersalthough the bottom water in the Guaymas Basin is oxic (Byrne and Emery, 1960). Hole 479 (water depth $=747$ m) penetrates a marginal plateau where the oxygenminimum layer impinges on the northwest continental slope of the Guaymas Basin. The mostly unconsolidated Pleistocene sediment consists of muddy diatomaceous ooze to mudstone, and many parts are rhythmically laminated. Seasonal variations of terrigenous sediment influx and diatom blooms supposedly cause the lamination (Byrne and Emery, 1960; Calvert, 1964, 1966).

\footnotetext{
${ }^{1}$ Curray, J. R., Moore, D. G., et al., Init. Repts. DSDP, 64: Washington (U.S. Govt. Printing Office).
}

This chapter deals with the nature and possible origin of the organic matter in the sediment of the Gulf of California. It also examines the environmental conditions during deposition. We emphasize the maturation effects-caused by the very high heat flow and, possibly, by the various basaltic intrusions-on the composition of the soluble and insoluble organic matter.

\section{SAMPLES}

The core samples and information on their origin, depth, stratigraphy, and lithology are listed in Table 1.

\section{EXPERIMENTAL PROCEDURES}

For a detailed description of the experimental procedures and conditions, including total and organic carbon determination, extraction, liquid chromatography, gas chromatography, gas chromatography/ mass spectrometry, and microscopy, see Rullkötter et al. (in press). Smear slides of the kerogen concentrates were prepared to determine structured liptinites (spores, algae, and the like) by transmitted-light microscopy. Under reflected light we took special care to discriminate between low-reflecting huminites and bituminous particles (i.e., unstructured liptinites). Huminites show a deep reddish-brownish fluorescence of low intensity, whereas immature fluorescing bituminous material is recognized by a yellowish-to-orange-reddish fluorescence of higher intensity and a strong positive alteration. In a few cases, this optical distinction could not unambiguously be made in the reflectance range of $0.2 \%$.

\section{RESULTS}

\section{Site 474, Mouth of Gulf of California}

Organic carbon (Table 1) ranges between 1 and $2 \%$ in Lithologic Units II through IV, whereas we determined 
Table 1. Organic- and carbonate-carbon values and extract data for Leg 64 core samples.

\begin{tabular}{|c|c|c|c|c|c|c|c|c|c|c|c|}
\hline \multirow[b]{2}{*}{$\begin{array}{c}\text { Sample } \\
\text { (interval in } \mathrm{cm} \text { ) }\end{array}$} & \multirow[b]{2}{*}{$\begin{array}{l}\text { Depth } \\
(\mathrm{m})\end{array}$} & \multirow[b]{2}{*}{ Age } & \multirow[b]{2}{*}{$\begin{array}{l}\text { Lithological } \\
\text { Unit }^{\mathrm{a}}\end{array}$} & \multirow[b]{2}{*}{ Lithology } & \multirow[b]{2}{*}{$\begin{array}{l}\mathrm{C}_{\text {org }} \\
(\%)\end{array}$} & \multirow[b]{2}{*}{$\begin{array}{l}\mathrm{C}_{\mathrm{carb}} \\
(\%)\end{array}$} & \multicolumn{2}{|c|}{ Extract } & \multicolumn{3}{|c|}{ Chromatographic Fractions (\%) } \\
\hline & & & & & & & (ppm) & (mg/g C org) & $\begin{array}{l}\text { Nonaromatic } \\
\text { Hydrocarbon }\end{array}$ & $\begin{array}{c}\text { Aromatic } \\
\text { Hydrocarbons }\end{array}$ & $\begin{array}{c}\text { Hetero- } \\
\text { Compounds }\end{array}$ \\
\hline $474-6-5,0-15$ & 46.0 & early Pleistocene & II & nanno-bearing silty clay & 1.24 & 0.57 & 101 & 8 & 7.9 & 2.3 & 89.8 \\
\hline $474 \mathrm{~A}-7-2,110-125$ & 223.1 & early Pleistocene & III & silty clay & 1.16 & 0.35 & 91 & 8 & 8.6 & 4.3 & 87.1 \\
\hline $474 A-21-6,48-63$ & 352.0 & early Pleistocene & IV & silty claystone & 1.49 & 0.66 & 108 & 7 & 16.8 & 8.4 & 74.8 \\
\hline $474 \mathrm{~A}-32-2,135-150$ & 450.7 & late Pliocene/carly Pleistocene & IV & silty claystone & 1.78 & 0.58 & 121 & 7 & 14.6 & 6.6 & 78.8 \\
\hline $474 A-40-3,120-140$ & 528.8 & early Pliocene & $\mathrm{v}$ & silty claystone & 0.52 & 0.47 & 26 & 5 & 22.2 & 13.0 & 64.8 \\
\hline $478-6-3,120-137$ & 45.8 & late Pleistocene & 1 & diatomaceous ooze & 1.37 & 0.54 & 113 & 8 & 12.6 & 6.9 & 80.5 \\
\hline $478-11-4,120-136$ & 94.8 & late Pleistocene & 1 & diatomaceous mud & 1.59 & 0.48 & 156 & 10 & 5.9 & 5.1 & 89.0 \\
\hline $478-17-4,120-139$ & 151.8 & late Pleistocene & lb & diatomaceous mud & 1.12 & 0.63 & 93 & 8 & 9.8 & 3.3 & 86.9 \\
\hline $478-28-4,120-140$ & 248.3 & late Pleistocene & II & diatomaceous claystone & 2.19 & 0.74 & 261 & 12 & 5.7 & 5.7 & 88.6 \\
\hline $478-35-5,110-125$ & 305.2 & late Pleistocene & $111 \mathrm{lb}$ & sand & 0.50 & 1.08 & 47 & 10 & 12,3 & 14.0 & 77.2 \\
\hline $481-8-2,130-140$ & 36.1 & late Pleistocene & 1 & diatomaceous mud & 1.54 & 0.69 & 76 & 5 & 9.1 & 13.6 & 77.3 \\
\hline $481 \mathrm{~A}-10-2,110-125$ & 130.2 & late Pleistocene & I & diatomaceous mud & $5.76^{\mathrm{b}}$ & $5.81^{b}$ & $1583^{b}$ & $27^{\mathrm{b}}$ & $0.8^{b}$ & $4.2^{\mathrm{b}}$ & $95.0^{\mathrm{b}}$ \\
\hline $481 \mathrm{~A}-22-4,126-150$ & 246.4 & late Pleistocene & I & diatomaceous mud & 1.92 & 0.47 & 314 & 16 & 12.3 & 11.9 & 75.8 \\
\hline $481 \mathrm{~A}-26-5,120-135$ & 286.8 & late Pleistocene & 1 & claystone & 1.31 & 0.92 & 115 & 9 & 15.9 & 14.6 & 69.5 \\
\hline $479-9-2,110-125$ & 72.2 & late Pleistocene & 1 & diatomaceous mud & 2.36 & 1.59 & 253 & 11 & 4.2 & 6.9 & 88.9 \\
\hline $479-17-5,120-135$ & 152.8 & late Pleistocene & 1 & diatomaceous mud & 2.19 & 0.07 & 286 & 13 & 4.0 & 6.5 & 79.5 \\
\hline $479-27-4,135-150$ & 246.4 & early Pleistocene & 1 & diatomaceous mud & 2.78 & 0.58 & 292 & 11 & 8.8 & 10.6 & 80.4 \\
\hline $479-34-5,110-125$ & 314.2 & early Pleistocene & II & diatomaceous mud & 3.13 & 0.57 & 259 & 8 & 10.1 & 12.5 & 77.4 \\
\hline $479-39-4,110-125$ & 359.2 & early Pleistocene & II & diatomaceous silty clay & 3.80 & 0.15 & 418 & 11 & 6.4 & 11.4 & 82.2 \\
\hline $479-47-4,110-122$ & 436.2 & early Pleistocene(?) & III & claystone & 1.15 & 1.35 & 96 & 8 & 23.8 & 13.8 & 62.4 \\
\hline
\end{tabular}

a See site chapters, this volume, Pt. 2.

b This sample probably is contaminated.

only $0.52 \%$ for the deepest section from Hole $474 \mathrm{~A}$ (474A-40-3). Carbonate carbon is below 1\% throughout. The values for the extractable organic matter, normalized to organic carbon, are below $10 \mathrm{mg} / \mathrm{g} \mathrm{C}_{\mathrm{org}}$ for all samples (Table 1), and there is no real depth trend. But the amount of hydrocarbons separated from the total extract seems to increase with depth. These data should be interpreted with great care because of the inaccuracy of weighing the very low, absolute quantities.

According to Rock-Eval pyrolysis (Espitalié et al., 1977), the organic matter from Hole 474 is Type III kerogen (Fig. 1). The hydrogen index values are low, and all samples are grouped near the Type III trend line. Our classification follows the scheme of Roucache et al. (1979) for immature, Cretaceous deep-sea sediment from the Atlantic Ocean.

The $n$-alkane distributions are similar in all samples from Hole 474 (Fig. 2A). Long-chain $n$-alkanes predominate, and their maxima are at $n-\mathrm{C}_{29}$ or $n-\mathrm{C}_{31}$. The predominance of the odd-numbered members indicates their origin from terrestrial, higher-plant waxes (Eglinton and Hamilton, 1963) and the immaturity of the organic matter. The concentrations of the isoprenoid hydrocarbons pristane and phytane are low; phytane is more abundant, except in the deepest sample (Fig. 2A). The samples from Units III and IV of Hole 474A contain unsaturated pristenes and phytenes. In all four samples from Hole $474 \mathrm{~A}$, we detected a $\mathrm{C}_{30}$-isoprenoid hydrocarbon with a retention time very similar to squalane (I), but according to the mass spectrum (Fig. 3A), it is a regular, head-to-tail linked isoprenoid (II; see Appendix for structural formulas). Albaigès et al. (1978) found this compound to be a minor constituent of crude oils within a series of $\mathrm{C}_{25}$ - to $\mathrm{C}_{40}$-isoprenoid hydrocarbons. In the Hole $474 \mathrm{~A}$ samples, the concentration of Compound II increases with depth (Fig. 2A), and it is a major component in the deepest sample (474A-40-3, $120-140 \mathrm{~cm})$.

The amount of cyclic nonaromatic hydrocarbons increases with depth in Lithologic Units II through IV, but is low in the Unit V sample. Steroidal compounds are generally more abundant than triterpenoids (Table

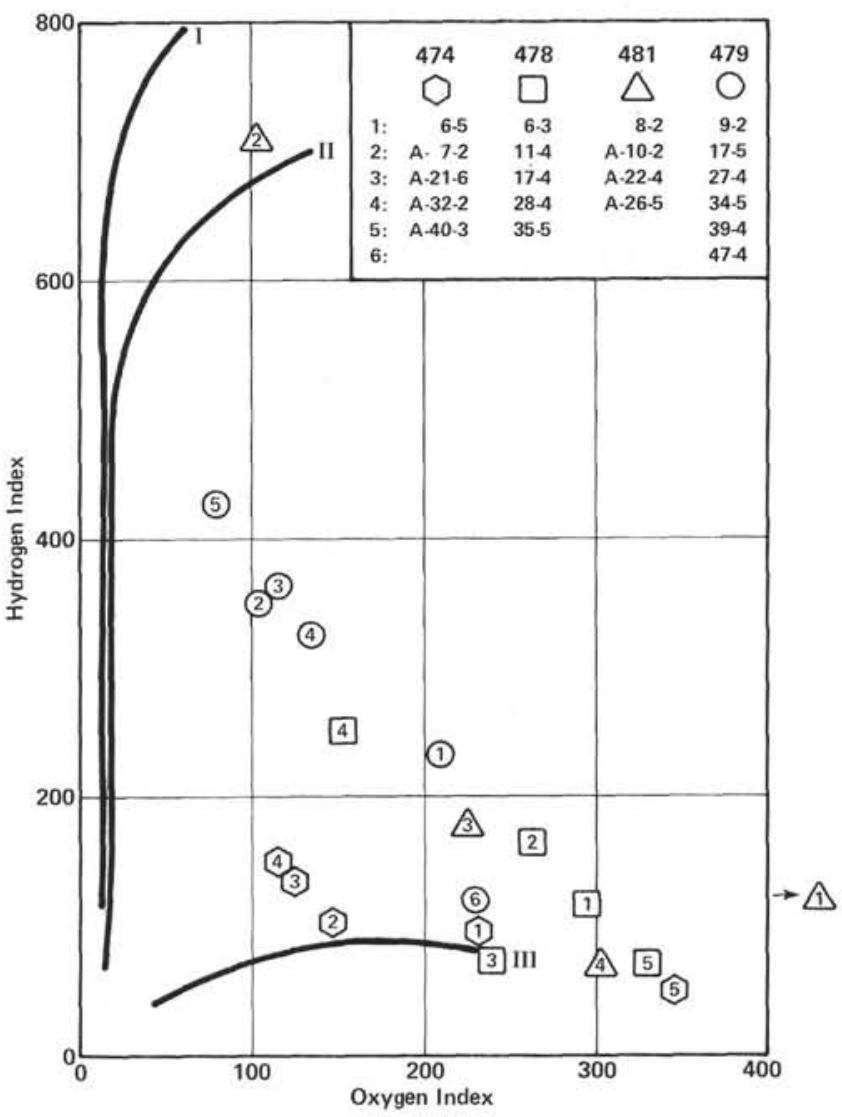

Figure 1. Rock-Eval pyrolysis displayed as hydrogen index versus oxygen index diagram. (Sample $2 \mathrm{~s}$ may be contaminated.)

2). Ster-4-enes and ster-5-enes (III) with slightly more abundant $\Delta^{4}$-isomers occur in all samples. Within the homologous series, the $\mathrm{C}_{27}$ and $\mathrm{C}_{29}$-members are similarly abundant, but their concentration considerably exceeds that of the $\mathrm{C}_{28}$-compounds. The $\mathrm{C}_{28}$-steradienes (IV, $\Delta^{4,22}$, and $\Delta^{5,22}$ ) are much more abundant than the $\mathrm{C}_{27^{-}}$and $\mathrm{C}_{29}$-homologs. Concerning the position of double bonds and relative concentrations, these results accord with previous findings for other deep-sea sedi- 


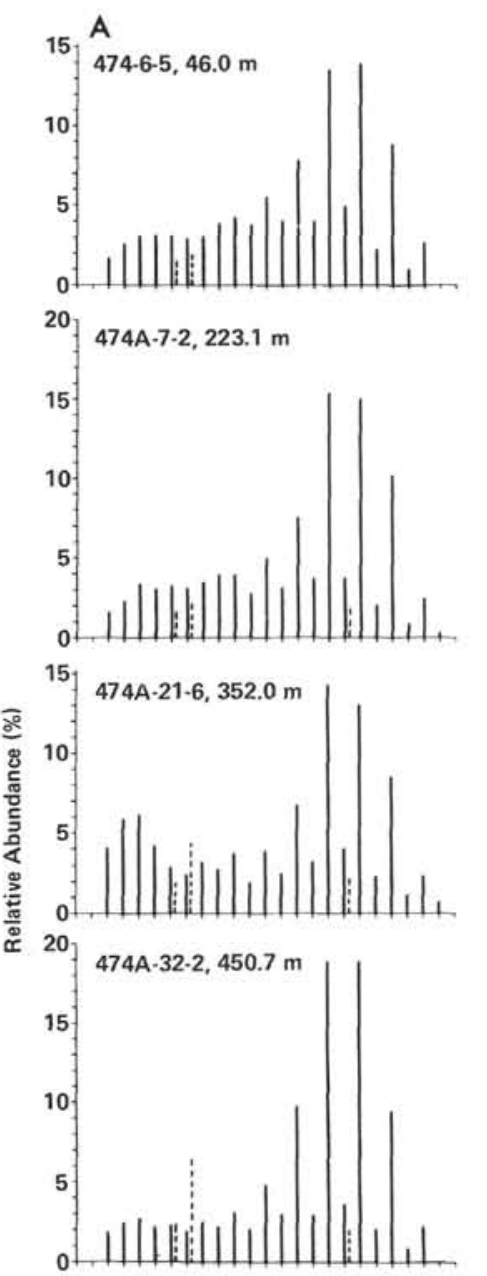

B
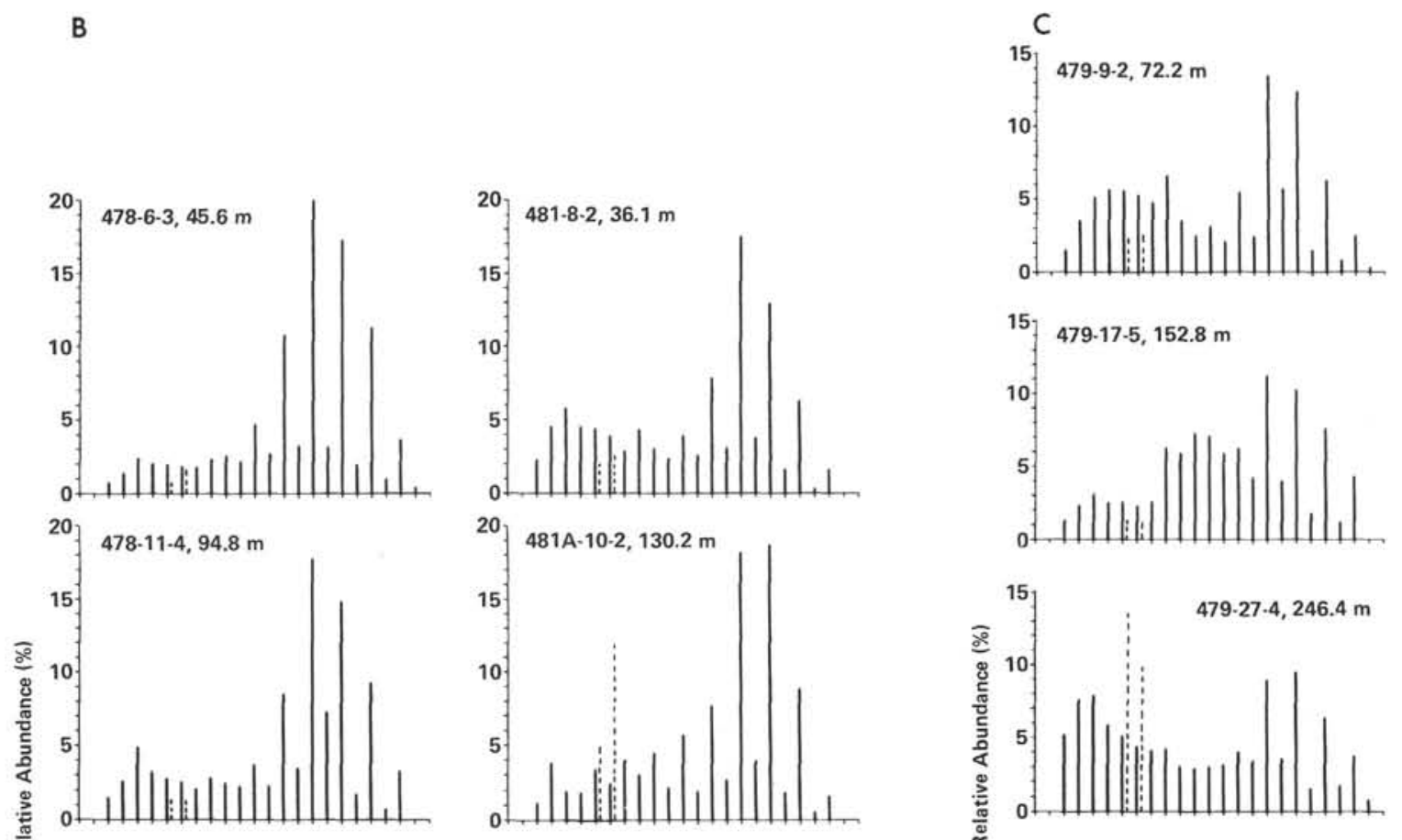

15. $479-17-5,152.8 \mathrm{~m}$

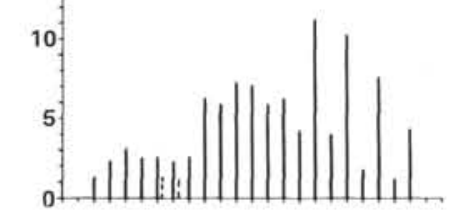

¿ 20
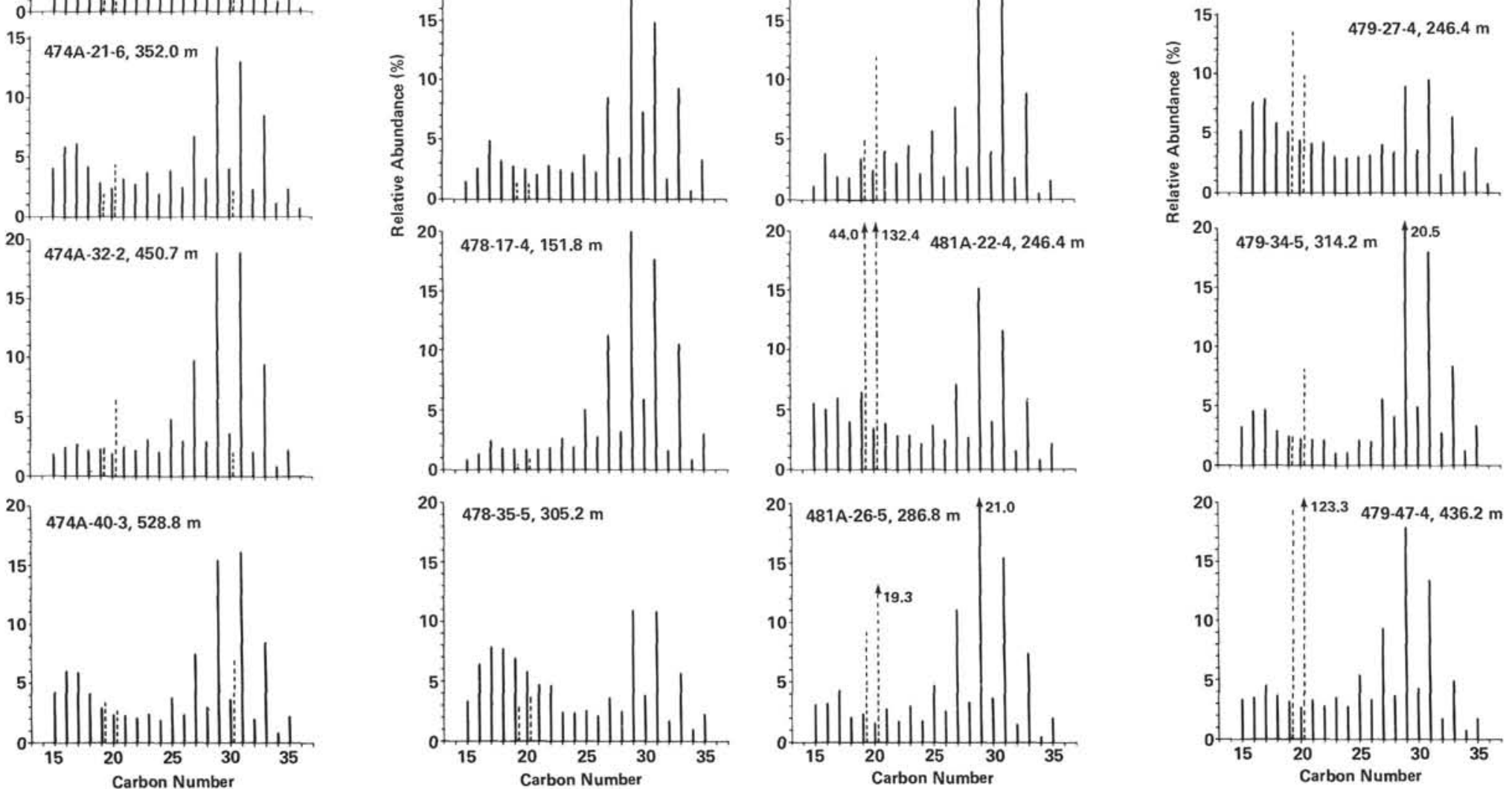

Figure 2. $N$-alkane (solid lines) and isoprenoid hydrocarbon (dotted lines) distributions. (Total $\mathrm{n}$-alkanes equal 100\%; isoprenoid hydrocarbon abundances are given relative to the $n$-alkanes. A. Holes 474 and 474 A. B. Holes 478 and 481 . C. Hole 479.)

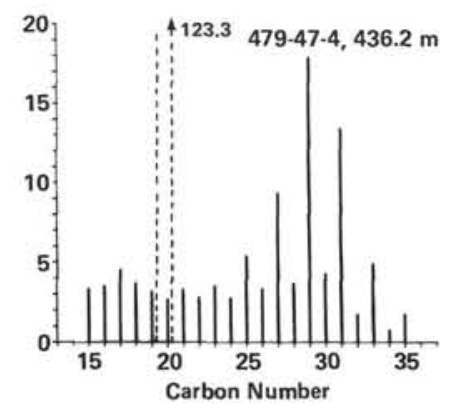



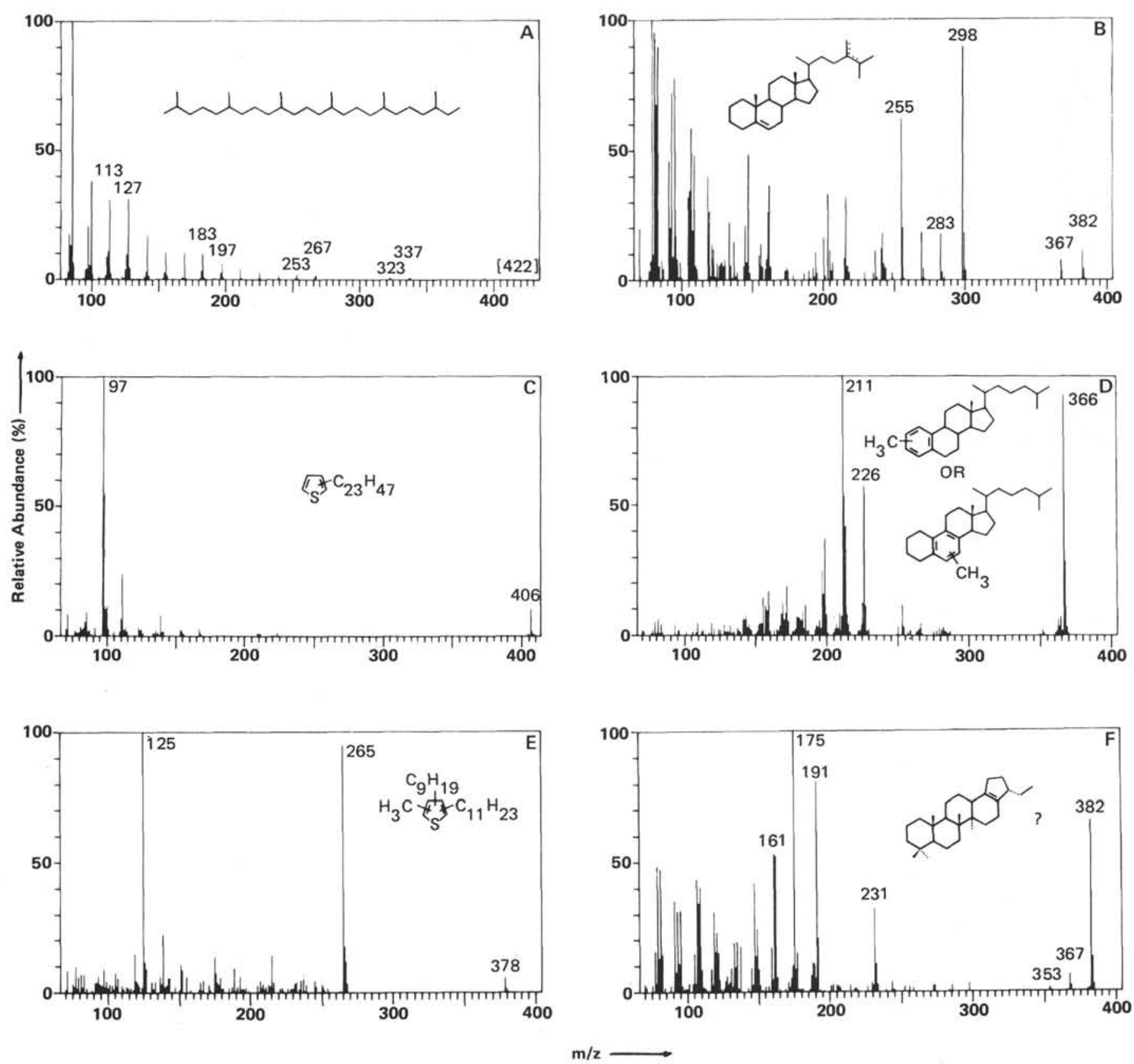

Figure 3. Mass spectra of new biological marker compounds in the hydrocarbon fractions of Leg 64 samples. (Structures are based on mass spectral interpretation. A. Regular head-to-tail linked $\mathrm{C}_{30}$-isoprenoid hydrocarbon (II). B. $\mathrm{C}_{28}$-stera-5,24-diene or stera-5,24(28)-diene (VI, R = H). C. Monoalkylated thiophene (XVIII). D. $\mathrm{C}_{27}$-monoaromatic steroid hydrocarbon aromatized in ring A or B (XXIII). E. Trialkylated thiophene (XIX). F. $\mathrm{C}_{28}$-triterpene.)

ment (see Rullkötter et al. [in press] for further references). Two other homologous steroid hydrocarbons $\left(\mathrm{C}_{28}\right.$ and $\left.\mathrm{C}_{29}\right)$ also occur in major concentrations in the Lithologic Unit II through IV samples. According to the mass spectra (Fig. 3B), these compounds are either stera-5,24-dienes or stera-5,24(28)-dienes (VI) (Wyllie and Djerassi, 1968; Massey and Djerassi, 1979). Steranes, 4-methyl- and rearranged steroid hydrocarbons, if present at all, do not exceed trace quantities.

Triterpenoid hydrocarbons, except for hop-17(21)ene (XII) which occurs in high concentrations in Lithologic Units III and IV, are minor constituents. In all samples, the $17 \beta(\mathrm{H})$-hopanes (IX) are more abundant than the $17 \alpha(\mathrm{H})$-hopanes $(\mathrm{X})$ and the moretanes $(\mathrm{XI})$.

Perylene (XVI) is the dominant aromatic hydrocarbon in all but the deepest sample. An alkyl-substituted thiophene, $\mathrm{C}_{27} \mathrm{H}_{50} \mathrm{~S}$ (XVIII; Fig. $3 \mathrm{C}$ ), is the next-most abundant compound in the aromatic hydrocarbon fractions of Samples 474-6-5, 0-15 cm and 474A-7-2, 110$125 \mathrm{~cm}$. We also detected this compound and other alkylated thiophenes in the deeper samples, but the concentrations rapidly decreased with depth. In the Unit IV and $\mathrm{V}$ samples, aromatic hydrocarbons (XX-XXII)most likely derived from triterpenoid precursors (Spyck- 
erelle et al., 1979a, b; Wakeham et al., 1980)-are also major constituents.

Only the two deepest samples (474A-32-2, 135-150 $\mathrm{cm}$ and 474A-40-3, 120-140 cm) contain small amounts of aromatic steroid hydrocarbons. They are monoaromatic compounds with an aromatized A- or B-ring (XXIII). We detected different isomers by GC/MS for molecular ions m/z $366\left(C_{27}\right.$; Fig. 3D) and m/z 394 $\left(C_{29}\right)$. Another series of isomers show molecular ions at $\mathrm{m} / \mathrm{z} 378$, which may correspond to $\mathrm{C}_{28}$-aromatic steroid hydrocarbons with an additional double bond in the side chain (XXIII). This parallels the homologous distribution of the sterenes/steradienes series in the nonaromatic hydrocarbon fractions. Sample 474A-40-3, 120$140 \mathrm{~cm}$ also contains some C-ring aromatized steroid hydrocarbons (Schaeffle et al., 1978). Furthermore, it shows a much greater variety of alkyl-substituted and unsubstituted aromatic hydrocarbons than the shallower samples. Most of these compounds are not resolved by capillary column chromatography but, rather, appear in a broad hump.

The type of organic matter in Holes 474 and 474A reflects the holes' sedimentary pattern. Lithologic Unit II, a redeposited and partially coarse-grained sediment (see site chapter, this volume), contains abundant rederived, eroded organic matter. This is obvious in Sample 474-6-5, 0-15 cm with the occurrence of bimacerites with vitrinite reflectances of 0.81 to $0.86 \%$ and corresponding inertinite reflectances of 1.16 to $1.25 \%$. The clear frequency maxima (Fig. 4A) support this interpretation. In the same sample, huminites, originating from higher plant debris, represent the reflectance range 0.2 to $0.35 \%$. But particles in the range 0.5 to $0.75 \%$ correspond to higher plant debris that has undergone oxidation or carbonization or to early diagenetic formation of inertinites. Liptinites are minor constituents and apparently also of higher plant origin. We observed no organic matter derived from marine organisms (Fig. $5 \mathrm{~A})$. The composition of the organic matter in Sample $474 \mathrm{~A}-7-2,110-125 \mathrm{~cm}$ is similar to that already described, although this lower sample contains more liptinites, especially bituminites (unstructured liptinites). The kerogen background matter of both samples mainly consists of gray and bright particles of apparently rederived and inertinite debris.

A remarkable change occurs in Lithologic Unit IV. Samples 474A-21-6, 48-63 cm and 474A-32-2, 135-150 $\mathrm{cm}$ contain highly bituminous background matter and high liptinite concentrations (Fig. 5A). Many bituminites in Sample 474A-21-6, 48-63 cm occur in different forms as dense isolated bodies, as intense impregnations of the background matter, and in transition from structured (algal?) liptinites to unstructured bituminites. Among the structured liptinites, the terrigenous influence (spores, pollen, and cuticles) predominates (Fig. $5 \mathrm{~A}$ ). Evidence for recycled organic matter in Sample 474A-32-2, 135-150 cm comes from some high-reflecting cuticles and spores.

The organic matter in Sample 474A-40-3, 120-140 cm (Unit V) is mostly terrigenous, higher-plant tissues represented by a major content of huminites $(0.25-0.35 \%$ reflectance). The corresponding semifusinites are in the reflectance range of 0.40 to $0.45 \%$ (Fig. $4 \mathrm{~A}$ ).

The reflectance of the huminites in the sediment from Holes 474 and 474A does not exhibit a clear trend of increasing maturity with depth. Even in Section 474A40-3, buried more than 500 meters and recovered near a dolerite sill, the reflectance data point to a low maturity stage.

\section{Sites 478 and 481, Guaymas Basin}

Most of the Guaymas Basin samples exhibit organic carbon values of between 1.1 and $2.2 \%$. Exceptions are the sand sample from Hole 478 (478-35-5, 110-125 cm) with $0.50 \%$ organic carbon and Sample 481A-10-2, $110-125 \mathrm{~cm}$ with an organic carbon value of $5.76 \%$. The amount of total extract and the chromatographic fraction values (Table 1) indicate that this latter sample is probably contaminated with polar, partly insoluble organic matter. The carbonate carbon value and the RockEval result (Fig. 1) also seem to be affected and will not be considered further. The extract values of the other samples are low and have no depth trend (Table 1).

The results of the Rock-Eval pyrolysis (Fig. 1) indicate that the kerogens in the sediment samples from the Guaymas Basin predominantly contain terrigenous organic matter (cf., Roucache et al., 1979). This is apparent from the low hydrogen and high oxygen index values. Only Sample 478-28-4, 120-140 cm shows a slightly higher hydrogen index and should contain relatively more liptinitic organic matter.

The $n$-alkane distributions of the three shallowest samples from Hole 478 (Lithologic Unit I/Ib) and all samples from Holes 481 and 481A are very similar (Fig. 2B). The long-chain $n$-alkanes are the most common and show maxima at $n-\mathrm{C}_{29}$ or $n-\mathrm{C}_{31}$. The odd carbon numbers are predominant. Sample 478-35-5, 110-125 $\mathrm{cm}$, which contains lower absolute amounts of $n$-alkanes, has a slightly different distribution. The lowmolecular-weight $n$-alkanes near $n-\mathrm{C}_{17}$ are more pronounced. Without separation from the branched and cyclic hydrocarbons, the amount of $n$-alkanes in Sample $478-28-4,120-140 \mathrm{~cm}$ is too low to be evaluated precisely (Fig. 6B). Pristane and phytane of nearly equal abundance or with a slight predominance of phytane occur in low concentrations in the samples from Holes 478 and 481 . These compounds are much more abundant in the Hole 481A samples, and phytane dominates pristane (Fig. 2B). Phytenes and pristenes occur in several samples (Table 2).

The three samples from Lithologic Unit I/IB of Hole 478 contain only small amounts of cyclic nonaromatic hydrocarbons (Fig. 6A). Steroid hydrocarbons occur in minor amounts, with the exception of 24-methylenecholest-5-ene or the $\Delta^{5,24}$-isomer (VI, R=H; Table 2). Within the hopane series, $17 \beta(\mathrm{H})$-homohopane is the most abundant compound. The two deeper samples from Lithologic Unit I/Ib contain large amounts of unsaturated hopenes as well (Table 2). Hop-22(29)-ene (XIV) is a major component only of Sample 478-11-4, $120-136 \mathrm{~cm}$. 
Table 2. Isoprenoid, steroid, and triterpenoid hydrocarbons identified in the nonaromatic hydrocarbon fractions of Leg 64 samples and marked in the gas chromatograms in Figures 6 and 7.

\begin{tabular}{|c|c|c|c|c|c|c|c|c|c|}
\hline \multirow{2}{*}{$\begin{array}{c}\text { GC } \\
\text { Peak }\end{array}$} & \multirow[b]{2}{*}{ Compound } & \multirow{2}{*}{$\begin{array}{l}\text { General } \\
\text { Structure }\end{array}$} & \multicolumn{7}{|c|}{ Section } \\
\hline & & & $474-6-5$ & $474 A-7-2$ & $474 A-21-6$ & $474 \mathrm{~A}-32-2$ & $474 \mathrm{~A}-40-3$ & $478-6-3$ & $478-11-4$ \\
\hline a & pristene & & & + & tr & + & & & \\
\hline b & phytenes & & & ++ & + & + & & & \\
\hline c & diacholestenes & VIII & & & & tr & tr & & \\
\hline d & 24-methyldiacholestenes & VIII & & & & $\operatorname{tr}$ & $\operatorname{tr}$ & & \\
\hline e & $5 \alpha$-norcholestane & VII & & & & & & & \\
\hline \multirow[t]{3}{*}{$f$} & $5 \beta$-cholestane & $\mathrm{v}$ & tr & & & & & & \\
\hline & cholesta-4,22-diene & IV & & + & + & + & + & & \\
\hline & cholesta-5,22-diene & IV & & + & + & + & + & & \\
\hline $\mathrm{g}$ & 24-ethyldiacholestene & VIII & & & & tr & $\operatorname{tr}$ & & \\
\hline $\mathrm{h}$ & cholest-4-ene & III & + & +++ & +++ & +++ & ++ & + & \\
\hline $\mathrm{i}$ & cholest-5-ene & III & $\mathrm{tr}$ & ++ & ++ & +++ & ++ & + & \\
\hline $\mathrm{j}$ & $5 \alpha$-cholestane & $\mathrm{V}$ & $\operatorname{tr}$ & & & & $\operatorname{tr}$ & tr & \\
\hline $\mathrm{k}$ & unknown $\mathrm{C}_{28}$-sterane & & & & & & & & \\
\hline 1 & 24-methylcholesta-4,22-diene & IV & & +++ & +++ & +++ & + & tr & \\
\hline $\mathrm{m}$ & 24-methylcholesta-5,22-diene & IV & & ++ & ++ & +++ & + & $\mathrm{tr}$ & \\
\hline $\mathrm{n}$ & 24-methyl-5 $\alpha$-cholest-22-ene & & & & & & & & \\
\hline o & $17 \alpha(\mathrm{H})$-trisnorhopane & $\mathrm{x}$ & + & + & + & + & + & tr & tr \\
\hline $\mathrm{p}$ & $17 \beta(\mathrm{H})$-trisnorhopane & IX & + & + & + & + & + & $\mathrm{tr}$ & + \\
\hline$q$ & 24-methyl-5 $\beta$-cholestane & $\mathrm{v}$ & $\operatorname{tr}$ & & & & & & \\
\hline $\mathrm{r}$ & 24-methyl-cholest-4-ene & III & + & + & + & + & + & tr & \\
\hline s & 24-methyl-cholest-5-ene & III & tr & + & + & + & + & tr & \\
\hline $\mathrm{t}$ & 24-methyl-5 $\alpha$-cholestane & $\mathrm{V}$ & tr & & & & tr & tr & \\
\hline u & 24-methylenecholest-5-ene (or $\Delta^{24}$-isomer) & V1 & ++ & ++ & + & + & & & ++ \\
\hline $\mathrm{v}$ & 24-ethyl- $5 \alpha$-cholest-22-ene & & & & & & & & \\
\hline w & $17 \alpha(\mathrm{H}), 18 \alpha(\mathrm{H}), 21 \beta(\mathrm{H})-28,30$-bisnorhopane & $\mathrm{XV}$ & & & & & & & \\
\hline $\mathrm{x}$ & 24-ethylcholesta-4,22-diene & IV & & ++ & + & + & + & & \\
\hline $\mathrm{y}$ & 24-ethylcholesta-5,22-diene & IV & & + & + & + & + & & \\
\hline $\mathrm{z}$ & $\mathrm{C}_{28}$-triterpene (cf., Fig. 3F) & & & & & & & & \\
\hline $\mathrm{a}^{\prime}$ & 24-ethyl-5 $\beta$-cholestane & $\mathrm{v}$ & & & & & & & \\
\hline \multirow[t]{2}{*}{$b^{\prime}$} & $\mathrm{C}_{30}$-terpadiene $(\mathrm{M}+408, \mathrm{BP} 134)$ & & & & & & & & \\
\hline & $17 \alpha(\mathrm{H})$-norhopane & $\mathrm{x}$ & + & + & + & + & + & tr & $\operatorname{tr}$ \\
\hline $\begin{array}{l}c^{\prime} \\
d^{\prime}\end{array}$ & $\begin{array}{l}\text { 24-ethylcholest-4-ene } \\
\text { unknown } C_{29} \text {-sterane }\end{array}$ & III & + & +++ & +++ & +++ & + & + & \\
\hline $\mathrm{e}^{\prime}$ & 24-ethylcholest-5-ene & III & tr & ++ & ++ & ++ & + & + & \\
\hline \multirow[t]{2}{*}{$f^{\prime}$} & 24-ethyl-5 $\alpha$-cholestane & $\mathrm{v}$ & tr & & & & $\operatorname{tr}$ & $\operatorname{tr}$ & \\
\hline & 24-ethylenecholest-5-ene (or $\Delta^{24}$-isomer) & VI & + & ++ & + & $\operatorname{tr}$ & & & + \\
\hline \multirow[t]{2}{*}{$g^{\prime}$} & hop-17(21)-ene & XII & + & + & +++ & +++ & + & $\mathrm{tr}$ & ++ \\
\hline & normoretane & $\mathrm{XI}$ & + & + & + & + & + & & \\
\hline$h^{\prime}$ & $\mathrm{C}_{30}$-triterpane & & & & & & & & \\
\hline$i^{\prime}$ & fernene(?) & & tr & & & & & & \\
\hline $\mathrm{j}^{\prime}$ & $17 \alpha(\mathrm{H})$-hopane & $\mathrm{x}$ & ++ & ++ & + & + & + & $\operatorname{tr}$ & + \\
\hline \multirow[t]{5}{*}{$\mathrm{k}^{\prime}$} & hop-13(18)-ene-II & XIII & $\operatorname{tr}$ & + & + & + & + & & + \\
\hline & $17 \beta(\mathrm{H})$-norhopane & IX & + & + & + & + & + & + & + \\
\hline & moretane & $\mathrm{XI}$ & $\mathrm{tr}$ & $\mathrm{tr}$ & tr & & & & \\
\hline & $17 \alpha(\mathrm{H})$-homohopane ( 2 isomers) & $\mathrm{x}$ & tr & $\operatorname{tr}$ & tr & tr & tr & & + \\
\hline & $17 \beta(\mathrm{H})$-hopane & IX & + & ++ & + & + & + & + & $\begin{array}{l}+ \\
++\end{array}$ \\
\hline $1 \cdot$ & $17 \beta(\mathrm{H})$-homohopane & IX & ++ & +++ & ++ & ++ & + & + & ++ \\
\hline $\mathrm{m}$ & unknown isoprenoid hydrocarbon $\left(\mathrm{C}_{40}\right.$ ?) & & + & + & + & + & tr & + & + \\
\hline
\end{tabular}

Note: Compounds are listed in order of elution from the capillary column. Estimated abundances: $+++=$ major,$++=$ intermediate, $+=$ minor,

$\mathrm{tr}=$ trace. See Figures 6 and 7 for GC peak identification.

The composition of the nonaromatic hydrocarbon fractions of the two deepest samples from Hole 478 are alike and contain mostly cyclic compounds. The capillary column chromatogram of Sample 478-28-4, $120-140 \mathrm{~cm}$ is displayed in Figure $6 \mathrm{~B}$, and the compounds identified are listed in Table 2 . Sterenes and steradienes form the bulk of the cyclic compounds.

Sample $481-8-2,130-140 \mathrm{~cm}$ contains only small amounts of nonaromatic cyclic hydrocarbons. Hop-22 (29)-ene (XIV), 24-methylenecholest-5-ene (or its isomer; VI), and a series of sterenes (III) are the main components. In Sample 481A-10-2, 110-125 cm (probably contaminated, but nonaromatic hydrocarbon fraction is perhaps not affected) $17 \alpha(\mathrm{H}), 18 \alpha(\mathrm{H}), 21 \beta(\mathrm{H})-28,30$ bisnorhopane $(\mathrm{XV})$ and a series of triterpenes predominate (Table 2). Unsaturated steroid and triterpenoid hydrocarbons are the most common in the nonaromatic hydrocarbon fractions of the two deepest samples from Hole 481A (Table 2). Compared to the sterenes and steradienes, the concentration of steranes (V) is low.

In the aromatic hydrocarbon fractions of all samples from the Guaymas Basin, perylene (XVI) is the most abundant. It is accompanied in most cases by smaller amounts of methyl-, dimethyl-, and benzoperylene (XVII). Sample 478-6-3, 120-137 cm contains a variety of aromatic triterpenoid degradation products (Spycke- 
Table 2. (Continued).

\begin{tabular}{|c|c|c|c|c|c|c|c|c|c|c|c|c|}
\hline & & & & & & Section & & & & & & \\
\hline $478-17-4$ & $478-28-4$ & $478-35-5$ & $481-8-2$ & $481 \mathrm{~A}-10-2$ & $481 \mathrm{~A}-22-4$ & $481 \mathrm{~A}-26-5$ & $479-9-2$ & $479-17-5$ & $479-27-4$ & $479-34-5$ & $479-39-4$ & $479-47-4$ \\
\hline & + & & & & + & + & & tr & & + & + & + \\
\hline \multirow[t]{8}{*}{+} & + & & & & ++ & ++ & & + & & + & + & + \\
\hline & tr & $\mathrm{tr}$ & & tr & tr & & & & & & & + \\
\hline & $\operatorname{tr}$ & tr & & $\mathrm{tr}$ & $\mathrm{tr}$ & & & & & & & + \\
\hline & ++ & + & & & & & & & & & & \\
\hline & & + & & + & + & $\mathrm{tr}$ & & & tr & tr & tr & + \\
\hline & & & & & & + & & & & & + & \\
\hline & & tr & & & & + & & & & & + & \\
\hline & tr & tr & & $\operatorname{tr}$ & $\mathrm{tr}$ & & & & & & & + \\
\hline+ & +++ & ++ & + & + & +++ & +++ & + & & ++ & +++ & +++ & +++ \\
\hline \multirow[t]{4}{*}{+} & ++ & ++ & tr & + & ++ & +++ & + & & + & +++ & +++ & ++ \\
\hline & $\begin{array}{c}++ \\
+\end{array}$ & + & + & + & ++ & + & $\mathrm{tr}$ & & + & + & + & + \\
\hline & ++ & ++ & & & + & ++ & & & + & ++ & ++ & + \\
\hline & $\begin{array}{c}++ \\
+\end{array}$ & ++ & & & + & ++ & & & + & ++ & ++ & + \\
\hline+ & & + & + & $\mathrm{tr}$ & $\operatorname{tr}$ & $\mathrm{tr}$ & $\operatorname{tr}$ & $\mathrm{tr}$ & + & $\mathrm{tr}$ & $\operatorname{tr}$ & $\operatorname{tr}$ \\
\hline \multirow[t]{2}{*}{+} & & + & + & $\operatorname{tr}$ & $\operatorname{tr}$ & tr & $\mathrm{tr}$ & + & $\mathrm{tr}$ & $\mathrm{tr}$ & $\operatorname{tr}$ & tr \\
\hline & + & + & & + & + & tr & & & tr & $\operatorname{tr}$ & $\operatorname{tr}$ & + \\
\hline+ & ++ & + & $\operatorname{tr}$ & $\operatorname{tr}$ & ++ & + & $\mathrm{tr}$ & & tr & + & ++ & ++ \\
\hline \multirow[t]{2}{*}{+} & + & + & & & + & + & $\mathrm{tr}$ & & $\mathrm{tr}$ & + & + & + \\
\hline & + & + & & + & + & + & $\mathrm{tr}$ & & + & + & + & + \\
\hline \multirow[t]{6}{*}{+} & $\mathrm{tr}$ & + & ++ & & $\mathrm{tr}$ & tr & + & ++ & + & + & + & \\
\hline & ++ & ++ & & $+t+$ & & & & $+t+$ & & & & \\
\hline & + & & & 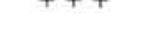 & & + & & $T+1$ & + & + & + & + \\
\hline & + & & & & & + & & & + & + & + & + \\
\hline & & & & & & & & +++ & & & & \\
\hline & $+t$ & + & & + & + & tr & & & tr & & $\mathrm{tr}$ & + \\
\hline+ & $\begin{array}{c}++ \\
\text { tr }\end{array}$ & + & + & + & + & + & $\mathrm{tr}$ & tr & $\mathrm{tr}$ & + & $\mathrm{tr}$ & $\mathrm{tr}$ \\
\hline+ & ++ & ++ & + & + & +++ & +++ & + & & + & +++ & +++ & ++ \\
\hline+ & $\begin{array}{c}+ \\
++\end{array}$ & ++ & $\mathrm{tr}$ & & ++ & ++ & + & & + & ++ & + & + \\
\hline & + & + & $\mathrm{u}$ & + & + & + & $\mathrm{tr}$ & & + & + & + & + \\
\hline $\mathrm{tr}$ & $\mathrm{tr}$ & $\mathrm{tr}$ & & & & & & & & & & \\
\hline \multirow[t]{3}{*}{++} & +++ & +++ & & ++ & +++ & +++ & ++ & +++ & +++ & +++ & +++ & +++ \\
\hline & & & & tr & & & & + & & + & + & \\
\hline & & & & + & & & ++ & ++ & ++ & ++ & + & \\
\hline+ & tr & + & + & + & + & tr & + & tr & $\mathrm{tr}$ & + & + & + \\
\hline+ & + & + & tr & ++ & + & + & + & ++ & ++ & ++ & ++ & + \\
\hline \multirow[t]{2}{*}{+} & $\mathrm{tr}$ & + & + & + & + & + & $\mathrm{tr}$ & + & + & + & + & + \\
\hline & & & & + & & + & & & & & & \\
\hline+ & & + & + & + & tr & tr & tr & tr & $\operatorname{tr}$ & tr & tr & tr \\
\hline+ & + & + & + & + & + & + & + & + & ++ & + & + & + \\
\hline++ & + & ++ & $\begin{array}{c}++ \\
+\end{array}$ & ++ & + & + & + & + & ++ & + & + & + \\
\hline+ & + & + & + & + & + & + & + & $++t$ & + & + & + & + \\
\hline
\end{tabular}

relle et al., 1979a, b). On the basis of their mass spectra (Wakeham et al., 1980), we have assigned them structures XX through XXII. Aromatic steroid hydrocarbons are not abundant in the Guaymas Basin samples. Single A- or B-ring aromatized compounds (XXIII; Fig. 3D) occur in Samples 478-6-3, 120-137 cm and 478-284, $120-140 \mathrm{~cm}$, whereas we detected a homologous series $\left(\mathrm{C}_{27}-\mathrm{C}_{29}\right)$ in the samples from Hole 481A. C-ring aromatized steroid hydrocarbons may be trace constituents. Two isomeric alkylated thiophenes, for which structure XIX is suggested on the basis of mass spectral interpretation (Fig. 3E), occur in the two deepest samples from Hole 478. The Hole 481A samples contain a greater variety of mono-, di-, and trialkylated thiophenes as major constituents. A hump of unresolved alkylated aromatic hydrocarbons, indicating thermal hydrocarbon generation and advanced maturity, is not pronounced in any of the samples.

Microscopy indicates that the organic matter in Sections 478-6-3, 478-17-4, and 478-35-5 is coaly, although the amount of liptinites (including some bituminites) is fairly high in Section 478-6-3 (Fig. 5B). The large amount of higher-reflecting particles $(\geq 0.4 \%)$ may be caused by oxidized (during transport), carbonized, or recycled organic matter (Fig. 4B).

Sample 478-11-4, 120-136 cm contains an extremely bituminous kerogen background matter and a large amount of liptinite particles (Fig. 5B). The majority of structured liptinites is terrigenous, and the contribution from marine organisms in minor. But as in Sample $474 \mathrm{~A}-21-6,48-63 \mathrm{~cm}$, the high content of inert, highreflecting particles is obvious (Figs. $4 \mathrm{~B}$ and 5B). Sample 

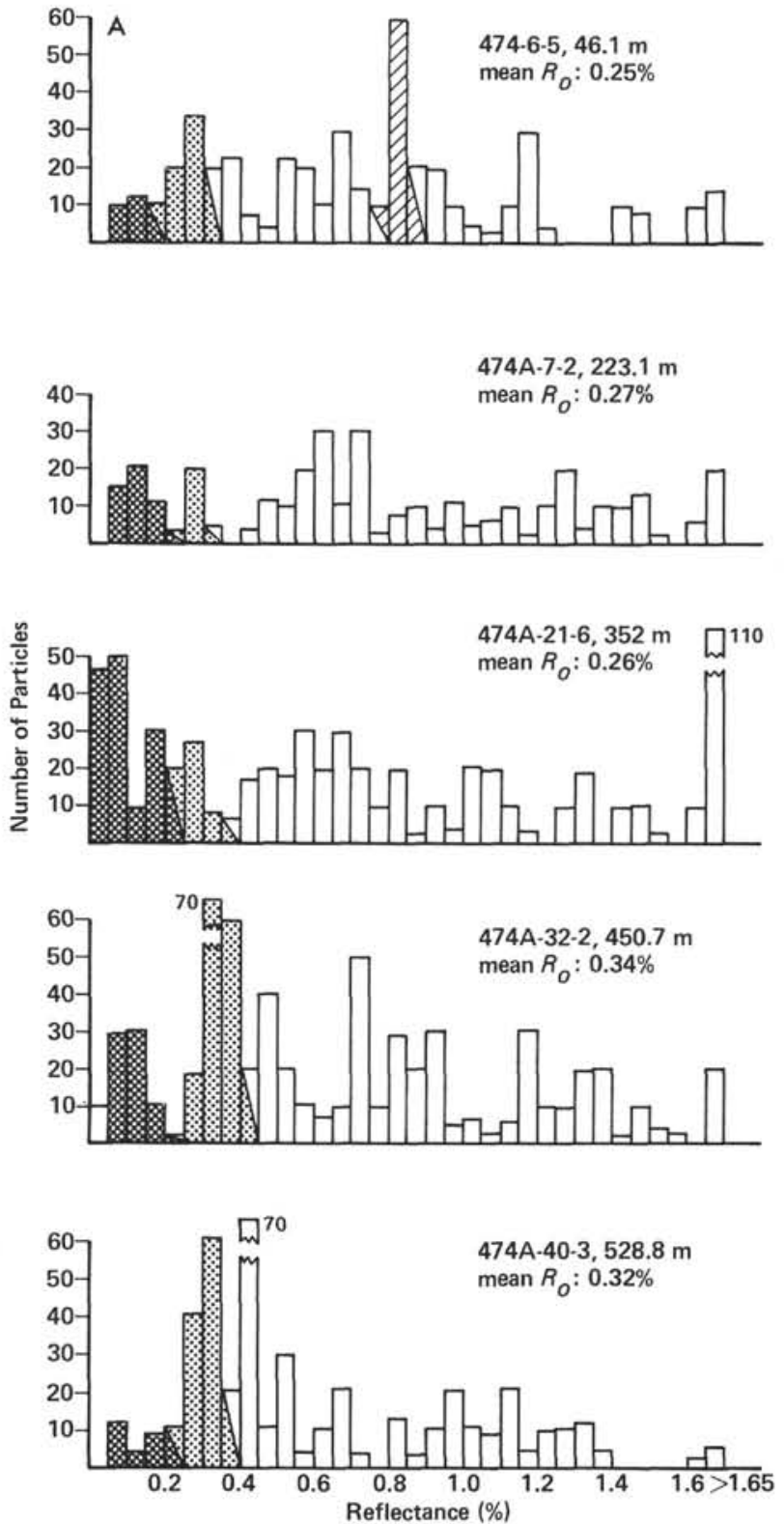

B
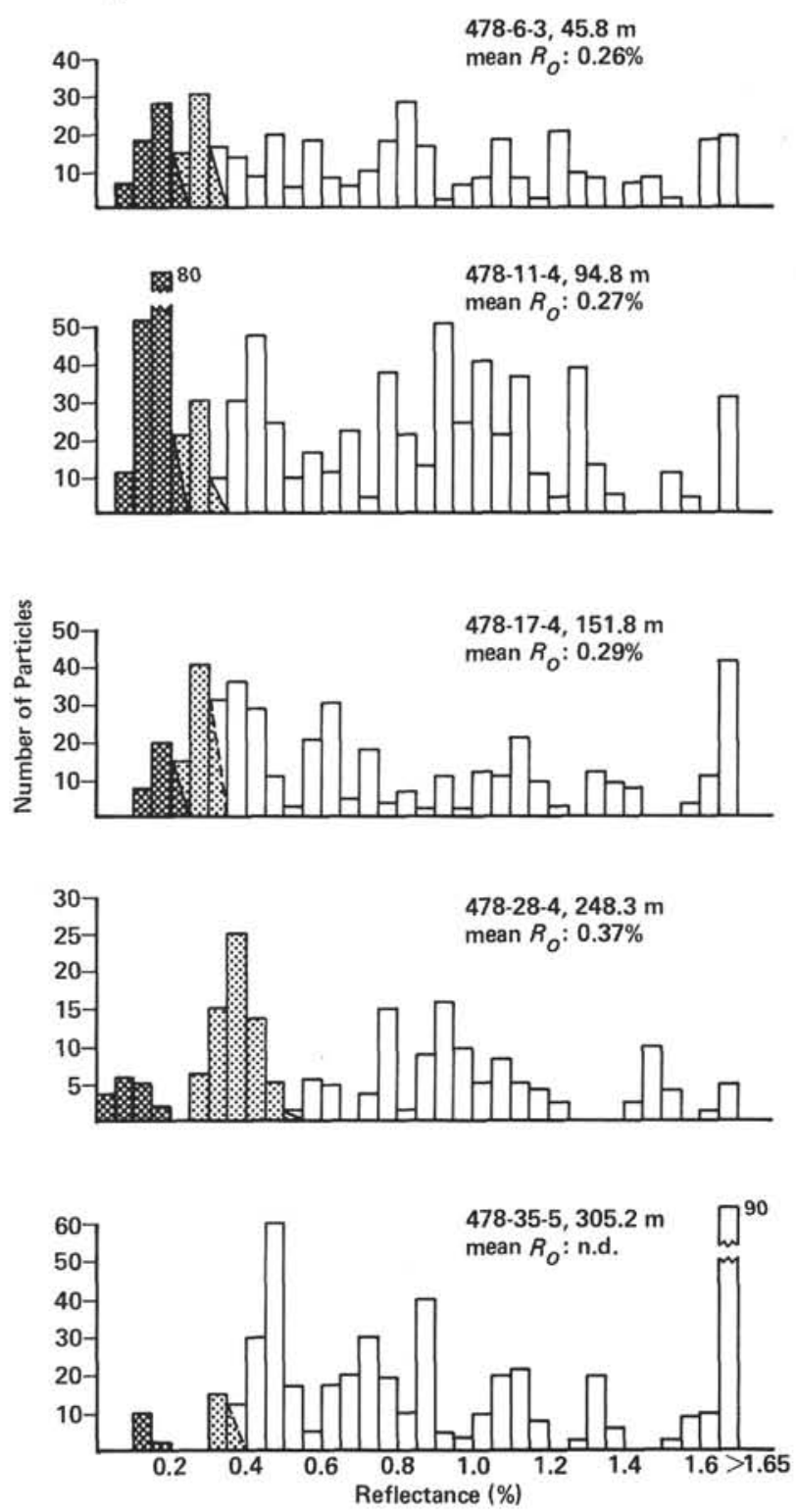

Figure 4. Reflectance histograms of liptinites, huminites (vitrinites), and inertinites larger than $10 \mu \mathrm{m}$ in kerogen concentrates. (Liptinites are not representative in all cases because their translucency and internal reflections prevent reflectance measurements. Mean huminite reflectance is given as $\bar{R}_{o}$-value. A. Holes 474 and 474 A. B. Hole 478 . C. Holes 481 and 481 A. D. Hole 479.)

478-28-4, 120-140 cm (Unit II) comprises mixed humic/ bituminous organic matter. Compared to the other samples from Hole 478, the amount of liptinite and crushed detrital particles in the kerogen is much higher (Fig. 5B).

With the exception of Sample 481A-10-2, 110-125 $\mathrm{cm}$, all kerogens isolated from the Hole 481 and 481A samples contain low-to-moderate amounts of liptinites and moderate amounts of inert ("dead") organic carbon. Its presence, as indicated by reworked spores in Sample 481A-22-4, 126-150 cm, may partly be attributed to recycled organic matter. The organic matter in these samples is Type III kerogen.

Amorphous bituminous kerogen composes the bulk of the organic matter in Sample 481A-10-2, 110-125 cm. (Fig. 5C); the sample has few particles with a reflectance higher than $0.35 \%$ (Fig. $4 \mathrm{C}$ ). It is not clear if this may be related to the suspected contamination.

Where an unambiguous identification of large primary huminite particles was possible, we observed only a slight increase in reflectance-and, thus, maturitywith increasing depth. In Hole 481, the mean huminite reflectance increases from $0.27 \%$ (Section $481-8-2$ ) to $0.35 \%$ (Section 481A-26-5). The two uppermost samples in Hole 478 show a mean huminite reflectance of 0.25 to $0.3 \%$. In Sample $478-17-4,120-139 \mathrm{~cm}$, we could not determine maturity because of the continuous frequency distribution in the reflectance range (Fig. 4B). Sample 478-28-4, 120-140 cm, interbedded between two dolerite sills, shows a majority of huminites in the range of 0.32 to $0.43 \%$ reflectance. In the deepest sample (478-35-5, 110-125 cm), some huminite particles appear 


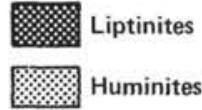

DT Contains 12 rederived Vitrinites $\square$ Inertinites
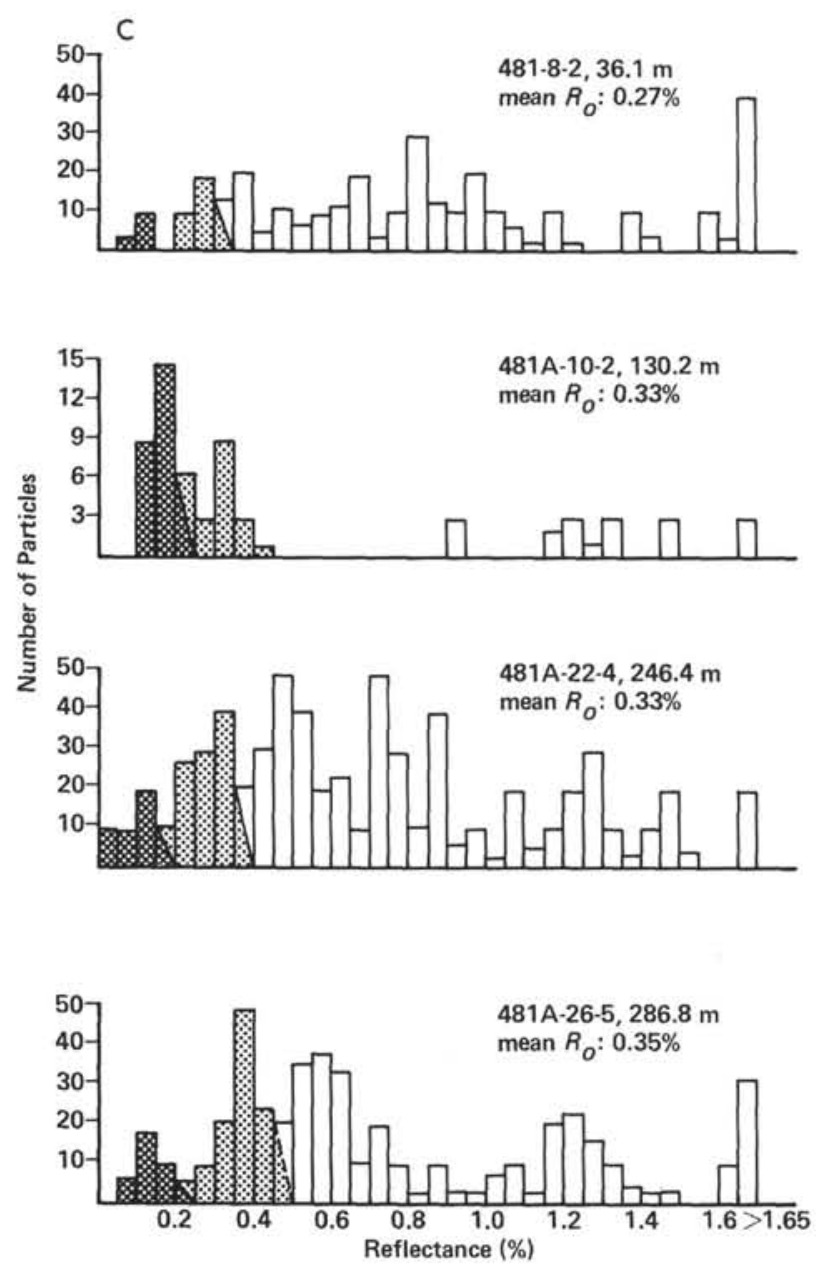

Figure 4. (Continued).

at 0.30 to $0.35 \%$ reflectance; the majority ranges from 0.40 to $0.50 \%$. We could not identify the primary nature of these latter particles.

\section{Site 479, Guaymas Basin Slope (oxygen-minimum zone)}

The organic carbon of the Guaymas Basin slope sediment is fairly abundant in the upper two lithologic units. The values range between 2 and $4 \%$ (Table 1). For a sample of laminated mudstone (Unit III), the organic carbon is $1.15 \%$. Carbonate is low and varies without
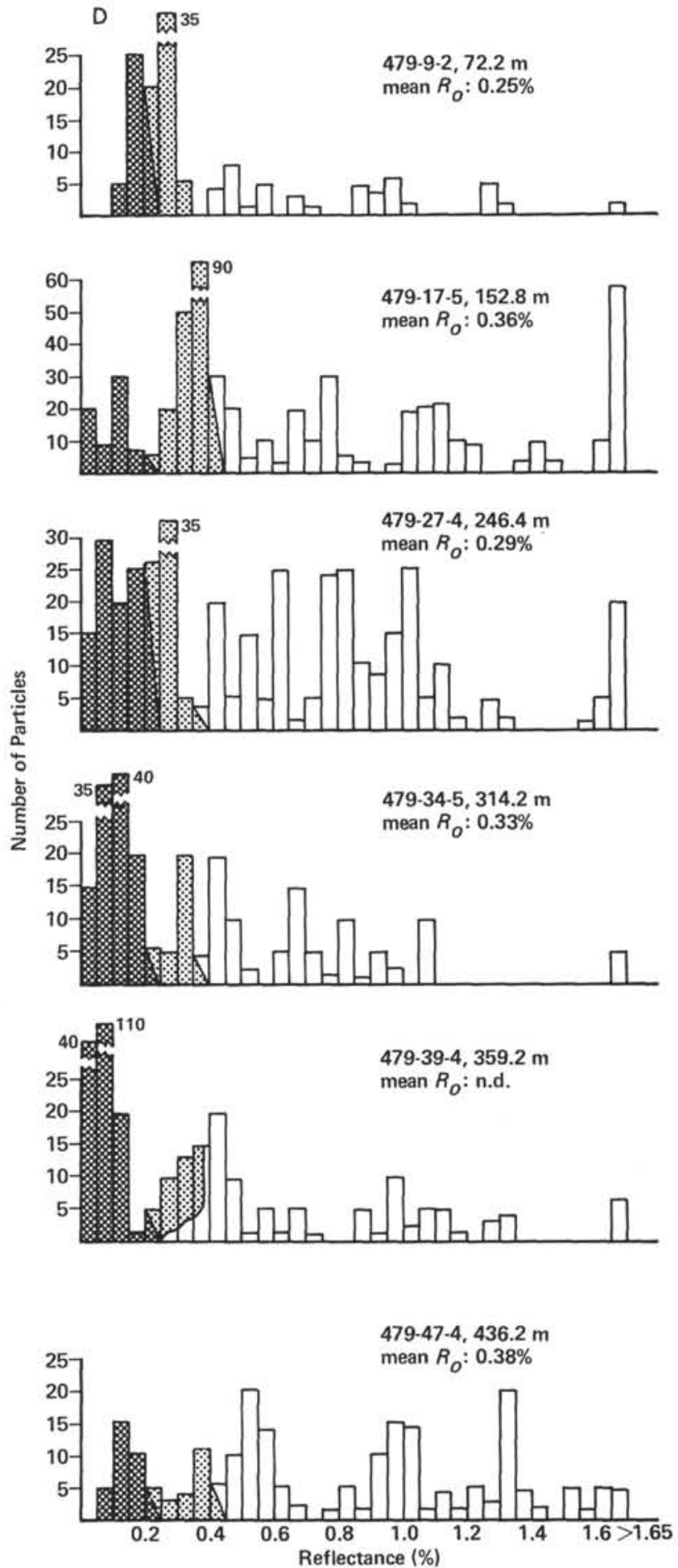

any trend (Table 1). The total extracts are between 8 and $13 \mathrm{mg} / \mathrm{g} \mathrm{C}_{\text {org }}$, and there is no increase deeper in the hole. We obtained a very high value for the nonaromatic hydrocarbon content of the deepest sample (Table 1), but this is not supported by the other results and the value probably is erroneous.

In the Rock-Eval diagram (Fig. 1), most of the Hole 479 samples are much closer to the Type II kerogen line; thus, the samples are more hydrogen-rich than those from other areas of the Gulf of California. But the 

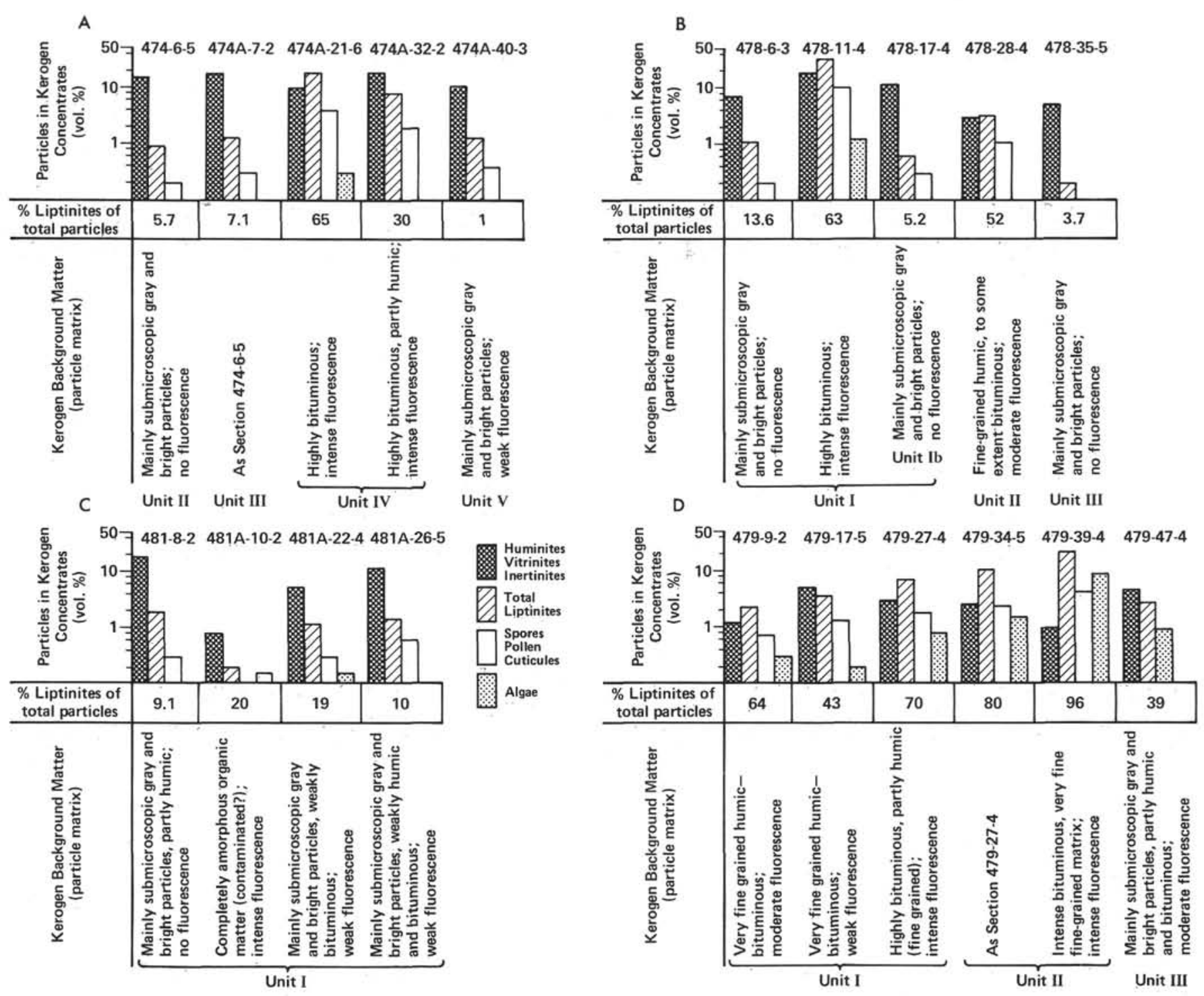

Figure 5. Amount and distribution pattern of macerals larger than $3 \mu \mathrm{m}$. (A. Holes 474 and 474A. B. Hole 478 . C. Holes 481 and 481 A. D. Hole 479.)

deepest sample $(479-47-4,110-122 \mathrm{~cm})$ does not follow this scheme.

With the exception of Sample 479-9-2, 110-125 cm, the nonaromatic hydrocarbon fractions are depleted in $n$-alkanes. Long-chain $n$-alkanes are less common in the Lithologic Unit I samples than in the deeper units (Fig. $2 \mathrm{C})$. In the shallower samples, pristane and phytane occur in low concentrations and in nearly equal abundance, whereas phytane predominates over pristane in the deeper sections and reaches a very high concentration in the lowermost sample. Pristenes and phytenes occur in the two deepest samples. We observed considerable amounts of a long-chain isoprenoid hydrocarbon $\left(\mathrm{C}_{40}\right.$ ?) in all samples (cf., Fig. 7).

Sample 479-9-2, 110-122 cm contains little (mostly triterpenoid) cyclic hydrocarbons (Table 2). Triterpenoids also predominate in Sample 479-17-5, 120-135 cm (Fig. 7A). Hop-17(21)-ene (XII) and an unknown $\mathrm{C}_{28}$ triterpene are the most abundant compounds. From its mass spectrum (Fig. $3 \mathrm{~F}$ ) it is possible that the triterpene is 28,30-bisnorhop-17(18)-ene, possibly diagenetically related to $17 \alpha(\mathrm{H}), 18 \alpha(\mathrm{H}), 21 \beta(\mathrm{H})-28,30$-bisnorhopane (XV) - the most abundant saturated triterpane in this sample. The only steroid hydrocarbon in any significant amount is 24-methylenecholest-5-ene (or its isomer; VI, $\mathrm{R}=\mathrm{H}$ ). Triterpenoid hydrocarbons are also the most prominent cyclic compounds detected in Sample 479$27-4,135-150 \mathrm{~cm}$, although the $\mathrm{C}_{28}$-triterpenoids are missing.

By contrast, sterenes and steradienes are the most common cyclic compounds in the lower three samples (cf., Fig. 7B; Table 2). In part, the composition is so complex that we could not identify all the major compounds. We observed that saturated steranes, relative to unsaturated steroids, increased with depth. But this trend is not pronounced, and the unsaturated compounds are still predominant in the deepest sample (Fig. 7B).

Perylene (XVI) is the most abundant aromatic hydrocarbon in all samples from Hole 479. Only the three 

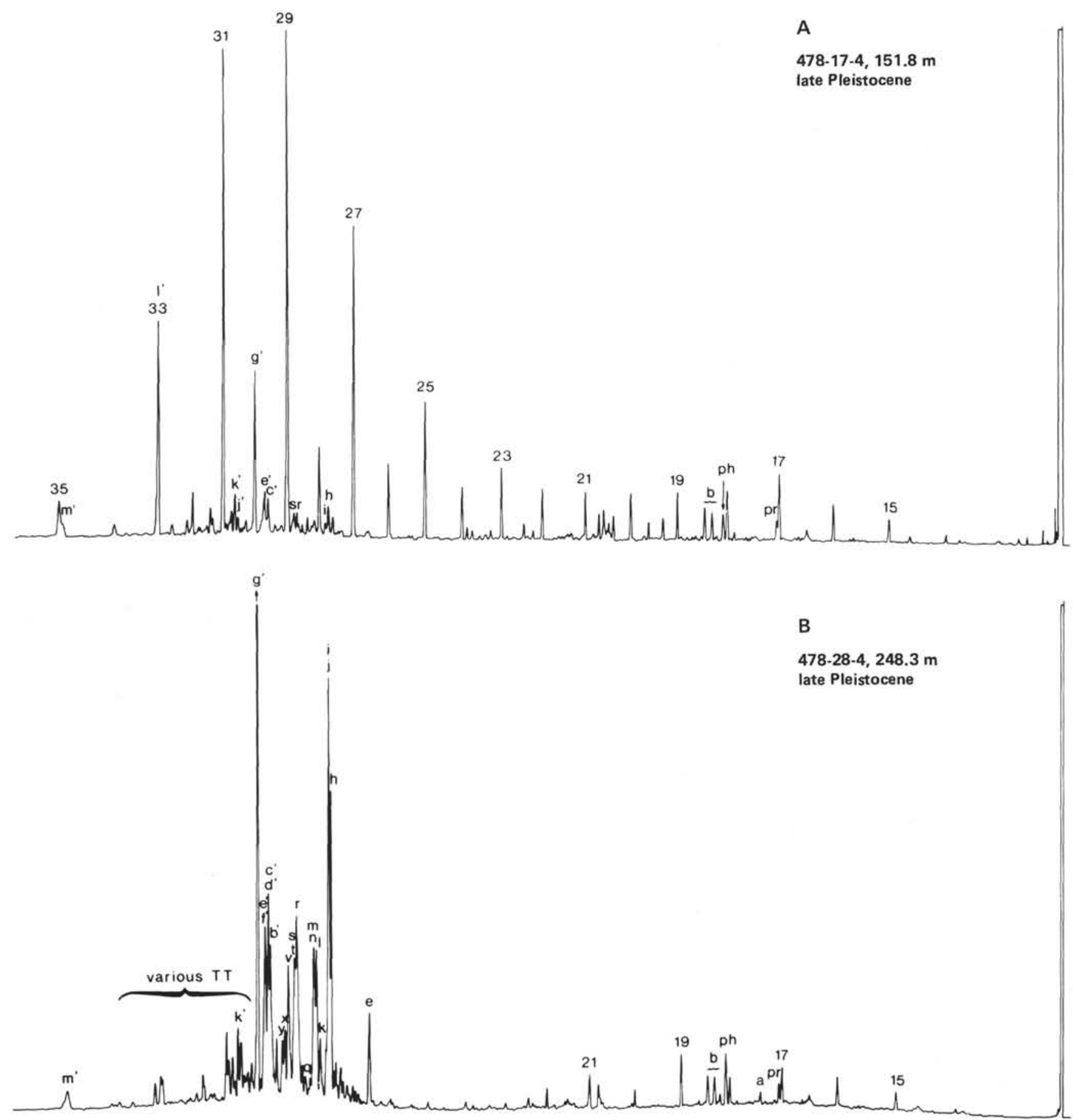

80

60

40

Retention Time (min.)

Figure 6. Capillary-column gas chromatograms of the nonaromatic hydrocarbon fractions of two core samples from Hole 478. ( $N$-alkanes are numbered. Compounds marked with letters were identified by GC/MS and listed in Table 2; pr = pristane, ph = phytane, TT $=$ triterpanes. Conditions: $20 \mathrm{~m} \times 0.3 \mathrm{~mm}$ i.d. SE 54 ; carrier gas = hydrogen; $80^{\circ} \mathrm{C}, 2 \mathrm{~min} .-80$ to $250^{\circ} \mathrm{C}, 3^{\circ} \mathrm{C} / \mathrm{min} .-250^{\circ} \mathrm{C}, 20 \mathrm{~min}$.).

samples from Lithologic Units II and III contain small amounts of thiophenes and a number of aromatic steroid hydrocarbons in higher concentrations. These are mainly from the aromatized A- or B-ring series (XXIII), but we also detected some C-ring aromatized and triaromatic steroid hydrocarbons. The appearance of aro- matic $\mathrm{C}_{28}$-steroids with an additional double bond in the side-chain, again, is consistent with the nonaromatic hydrocarbon fractions.

The kerogen concentrates of the hemipelagic muddy diatomaceous ooze from Hole 479 consist of an intimate mixture of unremoved, fine-grained mineral matter and 

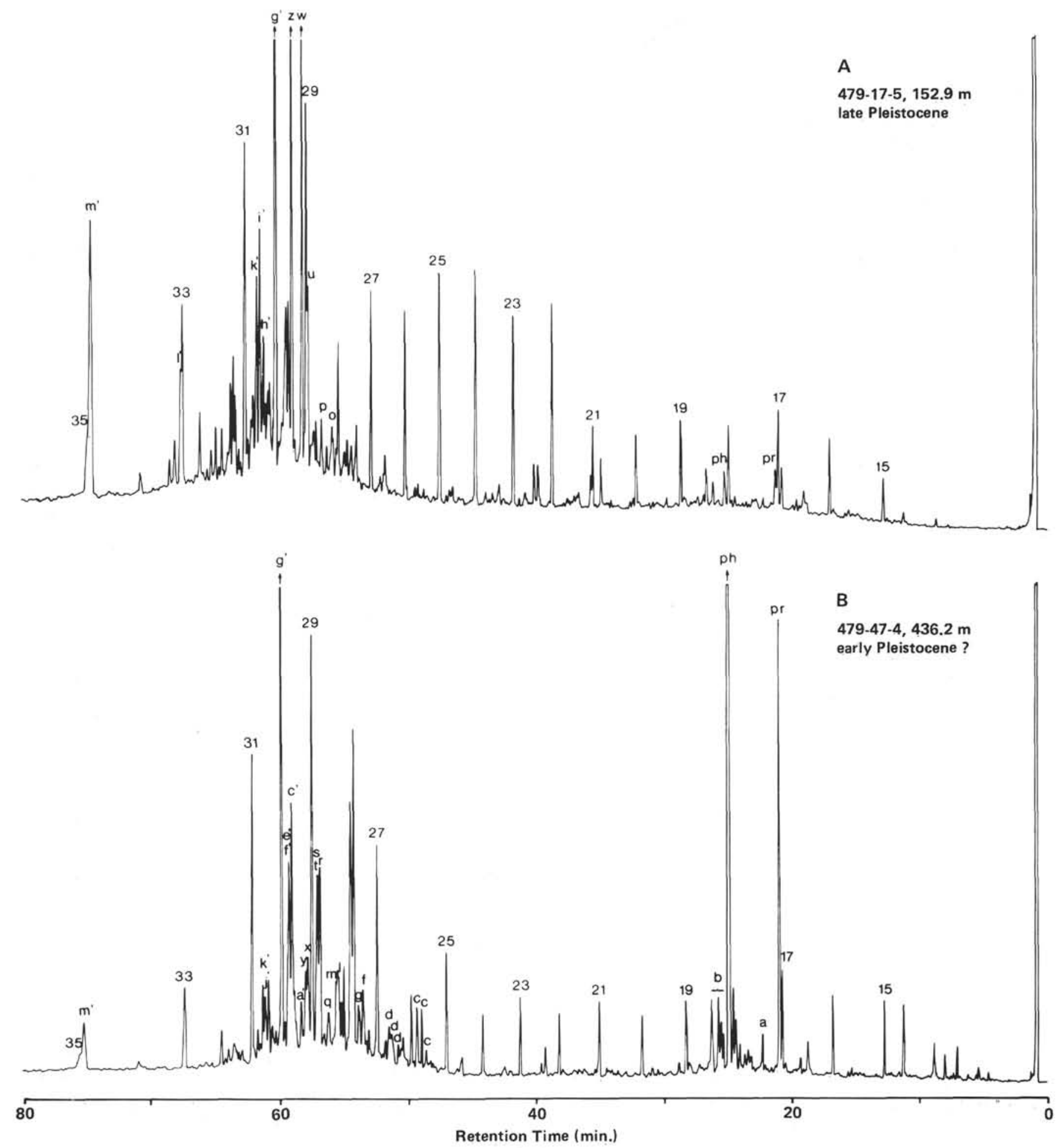

Figure 7. Capillary-column gas chromatograms of the nonaromatic hydrocarbon fractions of two core samples from Hole 479. (For identification and experimental conditions, see Fig. 6).

mainly liptinitic, partly bituminous, organic matter. The liptinites are especially enriched in Sections 479-274, 479-34-5, and 479-39-4, and there is a progressive down-hole trend paralleling the increasing contribution of algal material (Fig. 5D). The highest concentration of algal liptinites, exceeding terrigenous liptinites, occurs in Sample 479-39-4, 110-125 cm. According to smear- slide observation in transmitted light, the algae are hystrichosphaerides (probably dinoflagellate cysts [Eisenack, 1971]). A marked change in kerogen composition occurs in the laminated mudstone of Unit III (Section 479-47-4). Terrigenous organic matter is again predominant, although the liptinite content remains significant (Fig. 5D). The origin of the relatively high amounts of 
inertinites in Sections 479-17-5, 479-27-4, and 479-47-4 is uncertain.

The organic matter in Hole 479 samples is immature, and there is no significant change with increasing depth. All huminites fall in the reflectance range of 0.3 to $0.4 \%$ (Fig. 4D). Sample $479-27-4,135-150 \mathrm{~cm}$ has few particles in the range of 0.3 to $0.4 \%$ reflectance; but huminites may be represented in the 0.25 to $0.3 \%$ range (Fig. 4D). Thus the maturity determination for this sample is ambiguous, as it is in Sample 479-39-4, 110-125 cm, because of the continuous frequency distribution in the low-reflectance range. The deepest sample still exhibits low maturity with a mean huminite reflectance of $0.38 \%$, although the number of particles in the range of 0.35 to $0.45 \%$ may be too low for a reliable statement.

\section{DISCUSSION}

\section{Amount and Type of Organic Matter}

Turbidites predominate in most of the sediment sections from the mouth of the Gulf of California (Holes 474 and $474 \mathrm{~A}$ ) and the center of the Guaymas Basin (Holes 478, 481, and 481A). The organic carbon in these sediments varies, more or less, between 1 and $2 \%$ and is slightly higher than in the turbiditic sediments in Hole 471, Leg 63, off Baja California (Rullkötter et al., 1981). This may partly reflect the higher sediment accumulation rates, especially in the Guaymas Basin (more than $1200 \mathrm{~m} / \mathrm{m} . \mathrm{y}$. in Holes 478, 481, and 481A [Curray and Moore, et. al., 1979]), which result in organic matter better preserved by rapid burial during deposition in oxic bottom waters. We obtained lower organic carbon values for Sample 474A-40-3, 120-140 cm, possibly because of heavy bioturbation (see site chapter, this volume, Pt. 1), and for the turbidite sand sample (478-35-5, $110-125 \mathrm{~cm})$. The high organic carbon content in Sample $481 \mathrm{~A}-10-2,110-125 \mathrm{~cm}$ is not consistent with shipboard data for nearby samples (see site chapter) and may be the result of contamination. The sediment from the Guaymas Basin slope, deposited under oxygen-minimum conditions, has organic carbon between 2 and $4 \%$; thus, these samples are more enriched in organic carbon than the turbidite sediment.

There also is some variation of the type of organic matter in the sediment from different holes in the Gulf of California. Most of the samples from the mouth of the Gulf and the central Guaymas Basin mainly contain inert, terrigenous organic matter, whereas the sediment from the Guaymas Basin slope is enriched in liptinites and contains more marine organic matter. The organic matter from the Basin is Type III kerogen; that from the slope resembles Type II kerogens (Espitalié et al., 1977; Roucaché et al., 1979).

Low amounts of liptinite particles, relatively high amounts of inert carbon, and a kerogen background matter consisting of gray- and bright-reflecting small particles of probable detrital origin are typical of the Type III kerogens from the Gulf of California. The high-reflectance inertinite particles may be products of oxidation or carbonization, and varying amounts of both types cause significant variations of the oxygen index in the Rock-Eval diagram (Fig. 1).
Figure 8 is a diagram exclusively drawn from microscopical data. It presents a semiquantification of the maceral types to allow some correlation with geochemical data. Figure 8 plots the amount of inertinite and high-reflecting, rederived particles relative to primary huminites (up to $0.4 \%$ reflectance in the Leg 64 samples) as an index of inert carbon versus liptinite concentrations representing the hydrogen-rich, degradable part of the kerogens. Figure 8 implies a number of simplifications because the kerogen background matter is not considered, liptinites are not differentiated, no optical distinction is possible between oxidized and carbonized inertinites, and quantification of huminites is limited (scattered and disseminated in the kerogen background matter). But some relation to the pyrolysis diagram (Fig. 1) is obvious. All samples with a low hydrogen index and a high oxygen index show low liptinite and high inert carbon concentrations. Since the inert organic carbon index is fairly low (Fig. 8), the high oxygen index of Sample 481A-26-5, 120-135 cm (Fig. 1) may be attributed to the humic character of the kerogen. This is confirmed by the humic nature of the kerogen background matter (Fig. 5C). Similarly, since the inert carbon indices are high (Fig. 8) and the organic carbon is low (Table 1), the high oxygen content in Sections 478-6-3, 478-35-5 (sand), and 474A-40-3 (Fig. 1) is explained by strong oxidation of the organic matter. Carbonization may account for the low oxygen indices of the samples from Sections 474A-7-2, 474A-21-6, and 474A-32-2 (Fig. 1).

All samples (except the deepest) from Hole 479 form a single cluster in Figure 8 and contain high liptinite and low inert organic carbon concentrations. Within this group, there is a trend to higher liptinite concentrations with increasing depth. This trend can be seen in Figure 1 and is caused by an increasing algal contribution to the total organic matter (Fig. 5D). We do not know whether this reflects a decrease in bioproduction from lower to

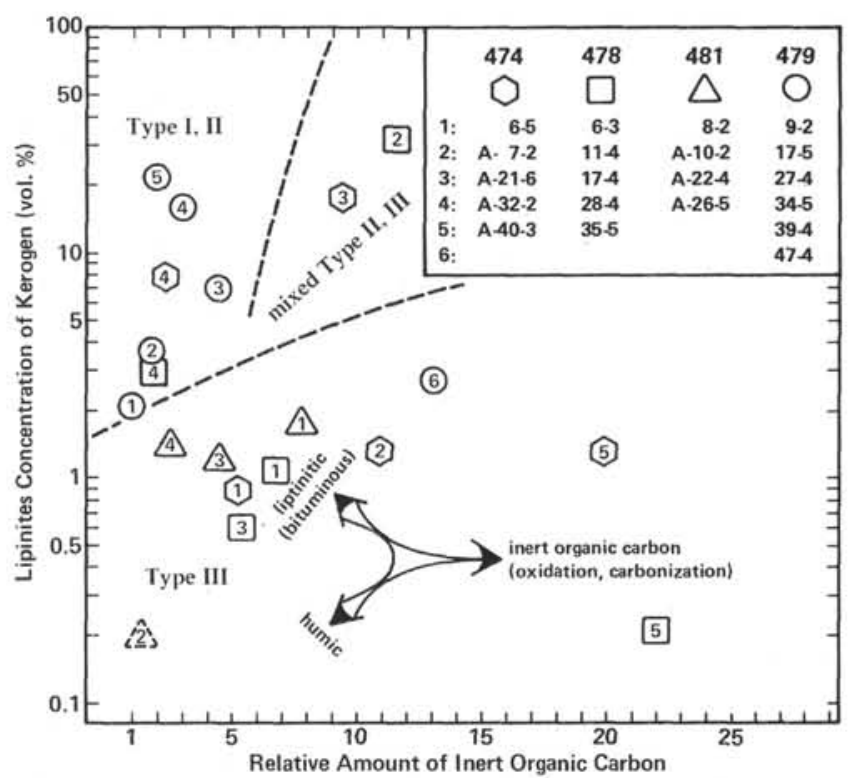

Figure 8. Inert organic carbon versus liptinite, Leg 64 samples. (Based on microscopical data. Sample 2 may be contaminated.) 
upper Pleistocene or a reduced preservation of the autochthonous organic matter caused by an increase in oxygen concentration in the water column. Because they are enriched in terrigenous liptinites (e.g., spores and pollen) and contain less inertinites than the other samples from the corresponding sites (cf., Fig. 1), samples 474A-32-2, 135-150 $\mathrm{cm}$ and 478-28-4, 120-140 $\mathrm{cm}$ fall in the same group as the Hole 479 samples.

Samples 474A-21-6, 48-63 cm and 478-11-4, 120-136 $\mathrm{cm}$ are slightly offset from the main groups (Fig. 8). Both samples, extremely rich in liptinites and bituminous background matter (Fig. 5A and B), contain high amounts of inertinite particles. This dilution by inert organic carbon results in low hydrocarbon yields (normalized to organic carbon) during pyrolysis (Fig. 1).

Amorphous (unstructured) liptinite particles occur in most of the samples from the Gulf of California. According to Teichmüller and Ottenjann (1977), this bituminous matter originates from the degradation of lipid- and protein-rich organisms that may be largely algae (Stach et al., 1975). Since all Leg 64 samples are in an early stage of diagenesis, the transformation of structured liptinites to amorphous organic matter is probably related to microbial activity. The bituminous matter is impregnated in the background matter or, if the bituminous matter forms the bulk of the kerogen, occurs as bituminite with organic and inorganic inclusions. This type of bituminite corresponds to the "bituminite I" described by Teichmüller and Ottenjann (1977), although in the Leg 64 samples the alteration under ultraviolet (UV) irradiation is positive. We identified another type, less abundant but more common in the Leg 64 samples, as relatively homogeneous particles with intense yellowish-to-reddish-fluorescence. Sometimes these bituminites have shrinking fissures (drying artifacts?) and resemble the "bituminite II"' (Teichmüller and Ottenjann, 1977).

In many respects, the analysis of the extractable hydrocarbons confirms the microscopy data. Because of the maxima at $n-\mathrm{C}_{29}$ or $n-\mathrm{C}_{31}$ and the strong odd-to-even carbon number predominance characteristic of plant wax (e.g., Eglinton and Hamilton, 1963), the $n$-alkane distributions of the samples from Holes 474, 474A, 478, 481 , and $481 \mathrm{~A}$ (Figs. 2A and $2 \mathrm{~B}$ ) reflect the predominantly terrigenous origin of the organic matter. In the Hole 479 samples, the $n$-alkanes near $n-\mathrm{C}_{17}$ are slightly more pronounced. But even samples containing high amounts of algal remains (e.g., 479-39-4, 110-125 $\mathrm{cm}$ ) do not show a predominance of the short-chain $n$-alkanes; these compounds are depleted or nearly absent. This is in contrast to some shallow, central Guaymas Basin core samples with $n$-alkane maxima at $n-\mathrm{C}_{17}$ and $n-\mathrm{C}_{19}$ (Simoneit et al., 1979). Another indication of the importance of allochthonous terrigenous organic matter in the Gulf sediments is the predominance of perylene in the aromatic hydrocarbon fractions. This marker compound (Aizenshtat, 1973) is also the most abundant aromatic hydrocarbon in samples containing large proportions of marine autochthonous organic matter-possibly because no aromatic hydrocarbons are formed from marine organic matter during early diagenesis (Wakeham et al., 1979; Rullkötter et al., in press). But Simoneit et al. (1979) detected no perylene in shallow sediment from the Guaymas Basin.

Sterenes and steradienes occur in varying concentrations in most of the sediments, whereas steranes generally occur as minor or trace constituents. There is little variation in the overall distribution pattern of the unsaturated hydrocarbons (e.g., Figs. 6B and 7B). $\mathrm{C}_{27}{ }^{-}$ and $\mathrm{C}_{29}$-sterenes (III $\Delta^{4}$ and $\Delta^{5}$ ) are of similar abundance but exceed the concentration of the $\mathrm{C}_{28}$-homologs. But the $\mathrm{C}_{28^{-}}$-steradienes (IV, $\Delta^{4,22}$ and $\Delta^{5,22}$ ) are found in higher concentrations than the $\mathrm{C}_{27^{-}}$and $\mathrm{C}_{29}$-homologs. The $\Delta^{4}$-isomers are always slightly more abundant than the $\Delta^{5}$-sterenes or $\Delta^{5}$-steradienes, but there are no indications of $\Delta^{2}$ - or $\Delta^{3}$-isomers. The same kind of distribution occurs in a number of slumped and turbiditic deep sea sediments (e.g., off the coast of Northwest Africa [Cornford et al., 1979], in the Japan Trench [Rullkötter et al., 1980], and off the California coast [Rullkötter et al., 1981]). This molecular weight distribution of steroid hydrocarbons, according to Huang and Meinschein (1979), falls in the range of typical marine or bay sediment. The concentration of unsaturated steroid hydrocarbons in most samples follows the trend of liptinite concentration as detected by microscopy. Although these are commonly terrigenous, this does not mean that the steroids are also related to terrigenous organic matter. It could indicate only that, in the sediment, the conditions for preserving the easily degradable lipid material was favorable. Some exceptions from the general trend may support this. No major amount of unsaturated steroids occur in Sample 478$11-4,120-136 \mathrm{~cm}$, although the amount of liptinite particles is high (Fig. 8). Despite the low liptinite concentrations (Fig. 8), the usual distribution of sterenes and steradienes is highly concentrated in Sections 478-35-5, 481A-26-5, and 479-47-4. This means that these compounds perhaps originate from very finely disseminated marine organic matter-perhaps with some contribution from terrestrial higher plant material-not readily detectable under the microscope.

One steradiene-24-methylene-cholest-5-ene or its $\Delta^{24}$-isomer (VI, R = H; Fig. 3B), which cannot be distinguished by mass spectrometry alone-occurs in most samples. Sometimes it is the only major steroid hydrocarbon (e.g., Fig. 7A) and occasionally is accompanied by the $\mathrm{C}_{29}$-homolog. But we lack the information to decide whether this compound, like perylene, is a marker for immature terrigenous organic matter.

We can estimate the influence of bacterial biomass in the Gulf of California sediment from the amount of triterpenoid hydrocarbon of the hopane series (De Rosa et al., 1971; Ourisson et al., 1979). Hop-17(21)-ene (XII) predominates in most of the samples (cf., Figs. 6B, 7A, and 7B). Perhaps it is the most stable isomer under the given conditions. Hop-22(29)-ene (XIV) is a major compound in the shallower samples from Holes 478, 481, and 481A; hop-13(18)-ene-II (XIII) is a minor component in most samples. We found only small amounts of saturated triterpanes, mainly $17 \beta(\mathrm{H})$-hopanes (IX). The $\mathrm{C}_{31}$-compound is the most abundant homolog. Traces 
of the more stable $17 \alpha(\mathrm{H})$-hopanes $(\mathrm{X})$ (Van Dorsselaer et al., 1977) may be attributed to the deposition of rederived, more highly mature organic matter in the Gulf of California. The only saturated triterpane detected at higher concentrations (in Sections 478-35-5, 481A-10-2, and 479-17-5) is a $\mathrm{C}_{28}$-hydrocarbon, $17 \alpha(\mathrm{H})$, $18 \alpha(\mathrm{H}), 21 \beta(\mathrm{H})$-28,30-bisnorhopane (XV), a major constituent of Monterey shale (Miocene) and California crude oils (Seifert et al., 1978). The transport of eroded material from Monterey shale supposedly accounts for the presence of this compound in deep sea sediment off the California coast (Rullkötter et al., 1981). The same mechanism could also explain this compound's existence in Gulf of California sediment. But the occurrence of a $\mathrm{C}_{28}$-triterpene in Sample 479-17-5, 120-135 cm (Figs. $7 \mathrm{~A}$, and $3 \mathrm{~F}$ ) suggests a local diagenetic formation, provided there is some relation between the two compounds.

A regular, head-to-tail-linked $\mathrm{C}_{30}$-isoprenoid hydrocarbon (II) is a characteristic constituent only of the samples from Holes 474 and 474A. Another long-chain isoprenoid hydrocarbon (of unknown structure) occurs in all samples but has a very high concentration only in Sample 479-17-5, $120-135 \mathrm{~cm}$ ( $\mathrm{m}^{\prime}$ in Fig. 7A). We do not know the precursor of either compound, and there is no obvious taxonomic relation.

\section{Maturity}

Vitrinite (or huminite) reflectance measurement most commonly determines the degree of coalification of organic matter and, thus, its maturity. Additional methods based on fluorescence studies have been developed, especially for the investigation of relatively immature sediments (Ottenjann et al., 1974; van Gijzel, 1975; Peters et al., 1977; Teichmuller and Ottenjann, 1977; Teichmüller and Wolf, 1977; Leythaeuser et al. 1980).

Discriminating between huminites and bituminous particles in bituminous sediments of low rank is difficult. Fluorescing bituminites in the Leg 64 samples seldom exceed a reflectance of $0.2 \%$. This allowed a separation of huminites from bituminites in the 0.2 to $0.25 \%$ range and is supported in most cases by the frequency distributions (Fig. 4). Huminites are also recognized by their insolubility in Canada balsam and immersion oil and their very weak, reddish-brownish fluorescence in the reflectance range up to $0.35 \%$. But in a few cases there is no sharp distinction between bituminite and huminite particles (Sections 479-27-4 and 479-47-4). Perhaps these sections contain bitumen-impregnated humic matter. Similarly, there was not always a clear separation of primary huminites and rederived organic particles.

Despite the extremely high heat flow and the various basaltic intrusions (Einsele et al., 1980), the sediment from the Gulf of California is immature. The mean huminite reflectance values are low. Although the values for the deepest samples are always higher than for shallow samples, there is considerable scatter and no regular real depth trend (Fig. 4). The scatter of huminite reflectance is caused by the biochemical coalification of humic material (Jacobs, 1975). The onset of oil generation at about $0.5 \%$ reflectance (Tissot and Welte, 1978) is not reached in any hole. Even in Section 474A-40-3 (the deepest sample [528.8 m]; located about three meters from a sill), the huminites still have a low mean reflectance (Fig. 4A). This is verified by the yellow fluorescence of the spores in the same sample (Ottenjann et al., 1974). Further evidence is the strong positive fluorescence alteration (after $30 \mathrm{~min}$. of UV irradiation) of the bituminous kerogen background matter. Teichmüller and Wolf (1977) showed that such a strong positive alteration is typical of a maturity below $0.4 \%$ mean huminite reflectance, whereas the onset of hydrocarbon generation and the release of larger amounts of hydrocarbons are characterized by no or negative alteration, respectively (Leythaeuser et al., 1980).

Neither does an investigation of the soluble organic matter provide any evidence for a considerable increase in maturation of the organic matter with increasing depth. The total extracts, normalized to organic carbon, remain more or less constant at all sites. Sterenes and steradienes are common in the deepest samples, and there is no indication (as in the Leg 63 samples from Holes 467 and 471 off California and Baja California [Rullkötter et al., 1981]) of a beginning conversion to saturated steranes. In the aromatic hydrocarbon fractions, we detected mostly A- or B-ring aromatized steroid hydrocarbons, whereas $\mathrm{C}$-ring aromatized steroids apparently predominate above about $0.4 \%$ huminite reflectance (Rullkötter et al., in press).

In maximum near-bottom-hole temperatures, which were more than $60^{\circ} \mathrm{C}$ in Holes $474 \mathrm{~A}$ and $481 \mathrm{~A}$ (see site chapters, this volume), a comparison with the maturation effects observed in Hole 471 ( Leg $63,60^{\circ} \mathrm{C}$ at about $600 \mathrm{~m}$ [Rullkötter et al., in press]) shows that time is as important for the maturation of organic matter as temperature. It is not the geothermal gradient that determines the maturation of organic matter but, rather, the integral heat flow that passed through the sediment.

\section{CONCLUSIONS}

The mostly turbiditic sediment at the mouth of the Gulf of California (Holes 474 and 474A) and in the Guaymas Basin (Holes 478, 481, and 481A) contains large amounts of allochthonous terrigenous organic matter and major proportions of oxidized or carbonized, partly reworked, inertinite material. The varying contributions of marine and bacterial biomass are recognized from the steroid and triterpenoid hydrocarbon distributions and may be represented by the bituminous kerogen background matter.

In the diatomaceous ooze of the Guaymas Basin slope sediment (Hole 479), algal liptinites form a major part of the kerogens and are increasingly abundant with depth. Low amounts of long-chain wax alkanes indicate the reduced influence of terrigenous organic matter.

All indicators of maturity point to a very immature stage of the organic matter in the Gulf of California sediment. Maximum mean huminite reflectances are near $0.4 \%$ and are consistent with the yellow spore color and the strong positive alteration of the bituminous organic matter. The extract yields do not increase with depth, and there are no indications of a beginning trans- 
formation of sterenes and steradienes to saturated steranes, even in the deepest samples. This emphasizes the importance of integral heat flow over longer periods for the maturation of organic matter in sediment.

\section{ACKNOWLEDGMENTS}

We are indebted to Dr. M. Radke, Dr. R. G. Schaefer, and U. Disko for extraction/liquid chromatography, gas chromatography, and processing mass spectrometric data, respectively. We also acknowledge the help of the technical staff of our institutes. We thank Dr. M. Bjorøy (IKU, Trondheim) and Dr. B. R. T. Simoneit (University of California, Los Angeles) for carefully reading and reviewing the manuscript. Samples were made available by participation of the Deutsche Forschungsgemeinschaft (DFG) in the DSDP/IPOD program. This and the financial support of the German Ministry of Research and Technology (BMFT), grant ET 3070 B, we gratefully acknowledge.

\section{REFERENCES}

Aizenshtat, Z., 1973. Perylene and its geochemical significance. Geochim. Cosmochim. Acta, 37:559-567.

Albaigès, J., Borbón, J., and Salagre, P., 1978. Identification of a series of $\mathrm{C}_{25}-\mathrm{C}_{40}$ acyclic isoprenoid hydrocarbons in crude oils. Tetrahedron Lett., 595-598.

Byrne, J. V., and Emery, K. O., 1960. Sediments of the Gulf of California. Geol. Soc. Am. Bull., 71:983-1010.

Calvert, S. E., 1964. Factors affecting distribution of laminated diatomaceous sediments in the Gulf of California. In van Andel, $\mathrm{Tj}$. H., and Shor, G. G. (Eds.), Marine Geology of the Gulf of California: Mem. Am. Assoc. Pet. Geol., 3:311-330.

1966. Origin of diatom-rich varved sediments of the Gulf of California. J. Geol., 74:546-565.

Cornford, C., Rullkötter, J., and Welte, D. H., 1979. Organic geochemistry of DSDP Leg 47A, Site 397, eastern North Atlantic: Organic petrography and extractable hydrocarbons. In von Rad, U., Ryan, W. B. F., et al., Init. Repts. DSDP, 47, Pt. 1: Washington (U.S. Govt. Printing Office), 511-522.

Curray, J. R., and Moore, D. G., et al., 1979. Leg 64 seeks evidence on development of basins. Geotimes, 24:18-20.

De Rosa, M., Gambacorta, A., Minale, L., et al., 1971. Bacterial triterpanes (thermophyllics). J. Chem. Soc. Chem. Commun., 3: 619-620.

Eglinton, G., and Hamilton, R. J., 1963. The distribution of $n$-alkanes. In Swain, T. (Ed.), Chemical Plant Taxonomy: London (Academic Press), pp. 187-217.

Einsele, G., Gieskes, J. M., Curray, J., et al., 1980. Intrusion of basaltic sills into highly porous sediments, and resulting hydrothermal activity. Nature, 283:441-445.

Eisenach, A., 1971. Katalog der fossilen Dinoflagellaten, Hystriosphären und verwandten Mikrofossilien: Stuttgart (E. Schweizerbart'sche Verlagsbuchhandlung).

Espitalié, J., Laporte, J. L., Madec, M., et al., 1977. Méthode rapide de caractérization des roches-méres, de leur potentiel pétrolier et de leur degré d'évolution. Rev. Inst. Fr. Pét. 32:23-42.

Huang, W.-Y., and Meinschein, W. G., 1979. Sterols as ecological indicators. Geochim. Cosmochim. Acta, 43:739-745.

Jacobs, H., 1975. Discussion remark. In Alpern, B. (Ed.), Colloquium International 1973, Pétrographie Organique et Potentiel Pétrolier: Paris (Ed. CNRS), p. 24.

Leythaeuser, D., Hagemann, H. W., Hollerbach, A., et al., 1980. Hydrocarbon generation in source beds as a function of type and maturation of their organic matter: a mass balance approach. Proc. 10th World Pet. Congr. 1979, 2: London (Heyden \& Sons), $31-41$.

Massey, I. J., and Djerassi, C., 1979. Structural and stereochemical applications of mass spectrometry in the marine sterol field. Synthesis and electron impact induced mass spectral fragmentation of $\Delta^{24}$ and $\Delta^{24(28)}-3 \beta$-hydroxy- $\Delta^{5}$-sterols. J. Org. Chem., 44:24482456.

Ottenjann, K., Teichmuller, M., and Wolf, M., 1974. Spektrale Fluoreszenz-Messungen an Sporiniten mit Auflicht-Anregung, eine mikroskopische Methode zur Bestimmung des Inkohlungsgrades gering inkohlter Kohlen. Fortschr. Geol. Rheinl. Westfalen, 24: $1-36$.

Ourisson, G., Albrecht, P., and Rohmer, M., 1979. The hopanoids. Paleochemistry and biochemistry of a group of natural products. Pure Appl. Chem., 51:709-729.

Peters, K. E., Ishiwatari, R., and Kaplan, I. R., 1977. Color of kerogen as index of organic maturity. Am. Assoc. Pet. Geol. Bull., 61:504-510.

Roucaché, J., Deroo, G., and Boulet, R., 1979. Caractérization par differentes méthodes physicochimiques de types de matière organique dans des sédiments du Cretacé d'Atlantique en mer profonde. Rev. Inst. Fr. Pét., 34:191-220.

Rullkötter, J., Cornford, C., Flekken, P., et al., 1980. Organic geochemistry of sediments cored during Deep Sea Drilling Project Legs 56 and 57, Japan Trench: Organic petrography and extractable hydrocarbons. In Scientific Party, Init. Repts. DSDP, 56, 57, Pt. 2: Washington (U.S. Govt. Printing Office), 1291-1304.

Rullkötter, J., von der Dick, H., and Welte, D. H., 1981. Organic petrography and extractable hydrocarbons of sediments from the eastern North Pacific Ocean, Deep Sea Drilling Project Leg 63. In Haq, B., Yeats, R. S., et al., Init. Repts. DSDP. 63: Washington (U.S. Govt. Printing Office), 819-835.

Schaeffle, J., Ludwig, B., Albrecht, P. et al., 1978. Aromatic hydrocarbons from geological sources. VI. New aromatic steroid derivatives in sediments and crude oils. Tetrahedron Lett., 41634166.

Seifert, W. K., Moldowan, J. M., Smith, G. W., et al., 1978. First proof of structure of a $\mathrm{C}_{28}$-pentacyclic triterpane in petroleum. Nature, 271:436-437.

Simoneit, B. R. T., Mazurek, M. A., Brenner, S., et al., 1979. Organic geochemistry of recent sediments from Guaymas Basin, Gulf of California. Deep-Sea Res. Part A, 26:879-891.

Spyckerelle, C., Greiner, A. Ch., Albrecht, P., et al., 1977a. Aromatic hydrocarbons from geological sources. Part III. A tetrahydrochrysene derived from triterpanes, in recent and old sediments: 3,3,7-trimethyl-1,1,3,4-tetrahydrochrysene. J. Chem. Res. MiniPrint, 1:3746-3754.

1977b. Aromatic hydrocarbons from geological sources, Part IV. An octahydrochrysene derived from triterpenes, in oil shale: $3,3,7,12$ a-tetramethyl-1,2,3,4,4a,11,12,12a-octahydrochrysene. J. Chem. Res. MiniPrint, 1:3801-3805.

Stach, E., Machowsky, M. Th., Teichmüller, M., et al., 1975. Stach's Textbook of Coal Petrology (2nd Ed.): Berlin (Gebrüder Borntraeger).

Teichmüller, M., and Ottenjann, K., 1977. Liptinite und lipoide Stoffe in einem Erdolmuttergestein. Erdöel Kohle Erdgas Petrochem., 30:387-398.

Teichmüller, M., and Wolf, M., 1977. Application of fluorescence microscopy in coal petrology and oil exploration. J. Microsc., 109: 49-73.

Tissot, B., and Welte, D. H., 1978. Petroleum Formation and Occurrence: Heidelberg (Springer-Verlag).

Van Dorsselaer, A., Albrecht, P., and Ourisson, G., 1977. Identification of novel $17 \alpha(\mathrm{H})$-hopanes in shales, coals, lignites, sediments and petroleum. Bull. Soc. Chim. Fr., 165-170.

Van Gijzel, P., 1975. Polychromatic UV-fluorescence microphotometry of fresh and fossil plant substances, with special reference to the location and identification of dispersed organic material in rock. In Alpern, B. (Ed.), Colloque International 1973, Pétrographie Organique et Potentiel Pétrolier: Paris (Ed. CNRS), pp. 67-91.

Wakeham, S. G., Schaffner, C., Giger, W., et al., 1979. Perylene in sediments from the Namibian Shelf. Geochim. Cosmochim. Acta, 43:1141-1144.

1980. Polycyclic aromatic hydrocarbons in Recent lake sediments-II. Compounds derived from biogenic precursors during early diagenesis. Geochim. Cosmochim. Acta, 44:415-429.

Wyllie, S. G., and Djerassi, C., 1968. Mass spectrometry in structural and stereochemical problems. CXLVI.-Mass spectrometric fragmentation typical of sterols with unsaturated side chains. J. Org. Chem., 33:305-313. 


\section{APPENDIX}

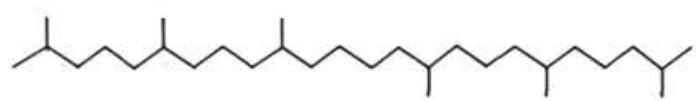

I. Squalane (tail-to-tail)

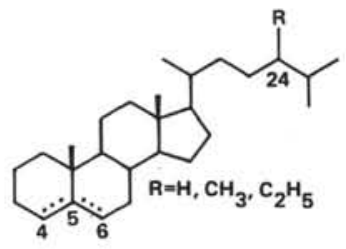

III. Sterenes<smiles>CC(C)CCC(C)C1CCC2C3CC[C@@H]4CCCC[C@]4(C)C3CCC12C</smiles>

VII. Norcholestane $\left(\mathrm{C}_{26}\right)$

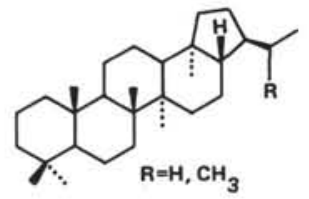

XI. Moretanes

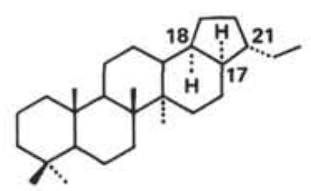

XV. $17 a(\mathrm{H}), 18 a(\mathrm{H})$, $21 \beta(H)-28,30$-bisnorhopane<smiles>Cc1cccc2c1CCC1C2CCC2(C)CCC(C)(C)CC12</smiles>

xX.<smiles>Cc1cccc2c1ccc1c3c(ccc12)CCC(C)(C)C3</smiles>

XXII.

IV. Steradienes

VIII. Diasterenes

XII. Hop-17 (21)-ene

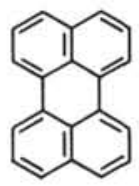

XVI. Perylene
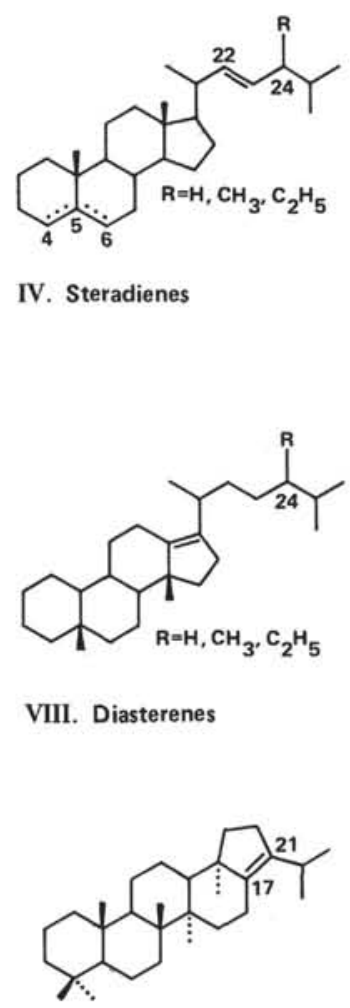<smiles>Cc1cccc2c3c(ccc12)C1CCC(C)CC1CCC3</smiles><smiles>Cc1cccc2c3c(ccc12)C1C(C)C(C)CCC1(C)CC3</smiles><smiles>Cc1cccc2c3c(ccc12)C1CC(C)(C)CCC1(C)CC3</smiles>

XXXI.

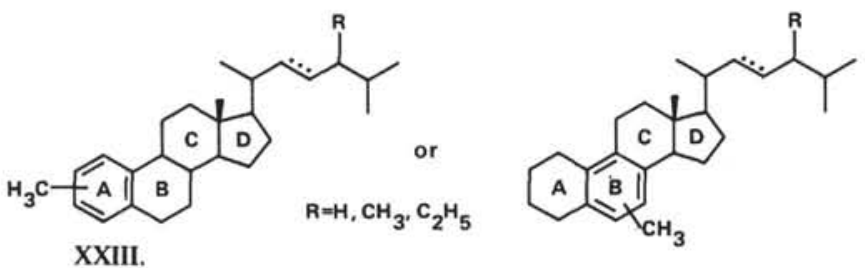

